\author{
Ante Petrović \\ Filozofski fakultet u Zagrebu \\ anpetrov@ffzg.hr
}

\title{
Polarne upitne rečenice u hrvatskome u dijakronijskoj i arealno-tipološkoj perspektivi
}

\begin{abstract}
U ovom se radu na temelju literature, korpusa i elicitacije opisuju načini kodiranja polarnih pitanja u hrvatskom jeziku i prikazuje se njihov dijakronijski razvoj. Pod pretpostavkom da je pragmatički motivirano obilježje poput načina kodiranja polarnoga pitanja arealno difuzno, hrvatski se stavlja u kontekst jezikā Europe te se predstavljaju upitne konstrukcije u odabranim starim i suvremenim jezicima. Zaključuje se da postoje određene arealne tendencije, koje se odražavaju i na hrvatski te se razvoj pojedinih upitnih konstrukcija u hrvatskom može tumačiti u skladu s njima.
\end{abstract}

\section{Uvod1}

U ovome će se radu sinkronijski i dijakronijski istražiti načini kodiranja polarnih pitanja u hrvatskome jeziku u njegovu arealnom kontekstu. Pitanja su govorni činovi koji služe za zahtijevanje informacije, jedno od triju glavnih funkcija jezika uz prenošenje informacije i zapovijedanje. Prema tim trima funkcijama rečenice se univerzalno mogu podijeliti na tri osnovne vrste, koje se u velikoj većini jezikā svijeta na neki način i formalno razlikuju (Givón 2001: 288): izjavnim se rečenicama prenose informacije, upitnim se rečenicama informacije zahtijeva, a zapovjednim se rečenicama nastoji postići da sugovornik učini nešto (usp. Velupillai 2012: 345-346). Odnos između forme rečenice i funkcije govornoga čina nipošto nije jednoznačan, niti su granice među vrstama govornih činova uvijek jasne, no ipak je tipološki utemeljeno govoriti o navedenim trima vrstama rečenica kao najčešće gramatikaliziranim prototipnim govornim činovima (Givón 2001: 288).

1 Ovaj se rad temelji na autorovu diplomskom radu na Odsjeku za lingvistiku Filozofskog fakulteta Sveučilišta u Zagrebu pod mentorstvom prof. dr. sc. Ranka Matasovića, kojemu zahvaljujem na pomoći. 
Upitne se rečenice dalje dijele na polarne ${ }^{2}$, o kojima će u ovom radu biti riječ, i na sadržajne ${ }^{3}$. Razlika je u tome što polarne upitne rečenice uglavnom zahtijevaju samo sugovornikovu procjenu istinitosne vrijednosti iskaza, odnosno odgovor ekvivalentan »da«, »ne«, ili eventualno takav poput »možda« ili »vjerojatno«, a sadržajne kao odgovor traže neku drugu informaciju naznačenu upitnom riječju. Primjer je polarne upitne rečenice u hrvatskom jeziku pod (1), a primjer sadržajne pod (2):

\section{(1) Čitali Ivica knjigu? \\ (2) Što Ivica čita?}

Valja odmah napomenuti da primjerice Mihaljević (1995: 19) inzistira na terminološkom razlikovanju upitne rečenice od pitanja, pri čemu bi prethodni pojam trebao biti definiran formalno, a potonji funkcionalno.

Polarnim se pitanjem može tražiti potvrda ili negacija za čitav iskaz ili za određeni element iskaza, koji je u tom slučaju izražen fokusiranim konstituentom (Givón 2001: 231-232). Fokus pritom shvaćamo kao jezičnu kategoriju koja upućuje na postojanje alternativa relevantnih za tumačenje izreke (Krifka i Musan 2012: 7). On na pojedinome sintaktičkom konstituentu, ovisno o jeziku, može biti kodiran intonacijom, položajem u rečenici, česticama ili afiksima (v. Givón 2001: 234) te tada ističe sadržaj izražen tim konstituentom u odnosu na alternative. Ovdje ćemo se u prvom redu baviti polarnim pitanjima bez fokusa, tj. onima koji propituju cijeli iskaz. Osim toga, jezici redovito raspolažu sredstvima kojima govornik u polarnome pitanju može kodirati očekivanje odričnoga ili potvrdnoga odgovora (Givón 2000: 292), no u ovom ćemo radu ta sredstva izostaviti iz razmatranja i koncentrirati se na polarna pitanja bez dodatne značenjske nijanse. Takva pitanja sasvim provizorno nazivamo neutralnim polarnim pitanjima.

Polarna pitanja u velikoj se većini jezikā svijeta formalno razlikuju od izjavnih rečenica, i to na taj način da su ona dodatno obilježena. Dryerovo (2013a) opsežno istraživanje na uzorku 955 jezika pokazuje da samo jedan jezik iz uzorka, mištek u Meksiku, nema formalnu distinkciju između polarnih upitnih i izjavnih rečenica. Također je izrazita rijetkost da se formalna opreka sastoji u tome što izjavne rečenice sadrže dodatne oznake izjavnosti, što je posvjedočeno u svega četirima jezicima u uzorku. Ostali tipovi upitnih konstrukcija svi uključuju dodatno ili posebno obilježavanje upitnih rečenica, a one su: posebna rečenična intonacija, upitna čestica, specijalizirana glagolska fleksija i poseban upitni red riječi. Kako ističe i Velupillai (2012: 352), mnogo se jezikā zapravo služi kombinacijom strategija, a Dryer od

2 U hrvatskoj su lingvistici još u uporabi termini potvrdno-niječna pitanja (Mihaljević 1995: 20) ijestno-niječna pitanja (Mihaljević 1997, 2007: 35), no smatramo da nijedan nije sasvim ukorijenjen. Stoga će se ovdje rabiti naziv polarna pitanja, koji je jasan ekvivalent engleskoga polar questions, uobičajenoga u suvremenoj tipološkoj literaturi (usp. Dryer 2013a, König i Siemund 2007: 292, Velupillai 2012: 352).

3 Mihaljević (1995: 25, 2007: 38) se koristi nazivima posebna pitanja i zamjenična pitanja, a naš je termin sadržajna pitanja po uzoru na content questions u Velupillai (2012: 356). 
kombinacija predstavlja jedino kombinaciju upitne čestice i glagolske fleksije, dok jezike koji se koriste nekom drugom kombinacijom svodi na jezični tip određen jednom od strategija. Time se u prvom redu nerealno umanjuje zastupljenost upitne intonacije, koju Dryer ubraja u upitne konstrukcije samo ako je to jedini način obilježavanja pitanja kojim jezik raspolaže, a za koju Velupillai (2012: 352, 353) tvrdi da je »vrlo uobičajena « te se često kombinira s bilo kojom drugom upitnom strategijom. Osim toga, svakako je moguća i kombinacija upitne čestice i posebnoga reda riječi, o čemu će biti više riječi kasnije u ovom radu. Prema Dryerovim kategorijama, najzastupljenija je strategija upitna čestica, posvjedočena u 585 ili 61.26 \% jezika u uzorku, a zatim upitna intonacija, koja je jedini način kodiranja polarnoga pitanja u 173 jezika, odnosno 18.12 \% uzorka. Međutim, sâm Dryer napominje da su jezici u kojima je intonacija jedini način kodiranja polarnoga pitanja podzastupljeni u uzorku te da ih je u stvarnosti više nego što bi se iz njega dalo zaključiti. Po učestalosti kao upitna strategija slijedi posebna glagolska fleksija, zabilježena u 164 jezika ili njih $17.17 \%$. Preostale dvije strategije znatno su rjeđe - kombinacija upitne čestice i glagolske fleksije javlja se u 15 ili $1.57 \%$ jezika, a poseban red riječi u 13 ili $1.36 \%$ jezika.

Jezici koji imaju upitnu česticu razlikuju se po njezinu položaju u rečenici. Dryer (2013b) pokazuje da je u većini jezikā smještena na kraju ili početku rečenice, znatno rjeđe na drugome mjestu u rečenici, a osobito rijetko na bilo kojem drugom položaju. Jezici s dominantnim poretkom glavnih sintaktičkih kategorija SOV skloni su pozicioniranju upitne čestice na posljednjem mjestu, oni s poretkom VSO skloni su upitnoj čestici na prvome mjestu, a u jezicima s poretkom SVO upitnaje čestica uobičajena i na prvom i na posljednjem mjestu (Dryer 2007: 109). Valja istaknuti da se u nekim jezicima čestica može smjestiti nakon fokusiranoga konstituenta, tj. onoga o kojem se traži informacija, no u većini takvih jezika postoji neutralni položaj čestice, u kojem ona jednako propituje čitav iskaz. U Dryerovu je istraživanju za takve jezik u obzir uzet taj neutralni položaj.

\section{Teorijsko polazište}

Ključan je pojam za naš rad jezični savez ilijezična area, koja se definira kao skup jezikā koji se govore na istom ili susjednom području te dijele niz zajedničkih obilježja koja nisu posljedica zajedničkoga podrijetla ili jezičnih univerzalija, nego jezičnih dodira među njima (usp. Campbell 2006: 454, Matasović 2001: 57). Pripadnost jezičnoj arei nije binarna kategorija, nego se naprotiv može govoriti o jezgrenim i rubnim članovima, ovisno o broju karakterističnih obilježja koji pojedini jezici imaju. Klasični je primjer jezične aree tzv. balkanski jezični savez, koji čine albanski, bugarski, makedonski, torlački srpski, novogrčki i rumunjski. Štokavski govori također imaju manji broj obilježjā toga saveza, primjerice perifrastični futur tvoren pomoćnim glagolom koji se razvio iz modalnoga volitivnog glagola (Thomason 2001: 109), no ne dovoljno njih da bi se smatrali pravim članom. 
Za naše je istraživanje osobito važna jezična area koja obuhvaća većinu suvremenih europskih jezika, a obično se naziva standardnim prosječnim europskim (kratica SPE, engleski Standard Average European, SAE) (Haspelmath 2001: 1492). Određena je nizom obilježjā, od kojih su mnoga rijetka u jezicima svijeta. Iako najveći dio jezikā SPE-a pripada indoeuropskoj jezičnoj porodici, većina njegovih obilježja sigurno nije naslijeđena iz praindoeuropskoga (Haspelmath 1998: 285).

Haspelmath (2001: 1505) određuje pripadnost jezika SPE-u prema jedanaest obilježja. Ustvrđuje da su s devet obilježja jezgreni članovi francuski i njemački, slijede nizozemski, albanski, portugalski, španjolski, sardski i talijanski s osam obilježja pa engleski te novogrčki i rumunjski s njih sedam. Periferniji su članovi sjevernogermanski jezici i češki sa šest obilježja te ostali baltoslavenski jezici i mađarski s pet obilježja. Izvan SPE-a ostali su keltski jezici, od kojih bretonski ima dva obilježja, velški jedno, a irski nijedno, baskijski, s dva obilježja, te turski i uralski jezici osim mađarskoga, koji nemaju nijedno od jedanaest obilježja. Iz izloženoga proizlazi, što Haspelmath $i$ ističe, da neki jezici balkanskoga jezičnog saveza ujedno imaju i velik broj obilježja SPE-a. Isti autor (1998: 285) smatra da je SPE najvjerojatnije nastao uslijed intenzivnih kontakata tijekom velike seobe narodā na prijelazu iz kasne antike u rani srednji vijek.

Matasović (2001: 63, 2002: 65) iznosi teze da pragmatički motivirana jezična obilježja imaju veliku arealnu difuznost, a nemaju dijakronijsku stabilnost, što znači da se često preuzimaju iz jezika u jezik i lako mijenjaju. Budući da je način formuliranja polarnih pitanja izravno povezan s vrstom govornoga čina te je kao takav izrazito pragmatički motiviran, polazeći od Matasovićeve teze, pretpostavlja se da će biti arealno difuzan. Iz toga proizlazi kako se može očekivati da je u SPE-u proširen jedan tip upitne konstrukcije, što je hipoteza koju smo mi pokušali provjeriti.

Haspelmath (2001: 1501) doista spominje premještanje glagola na početak rečenice u polarnim pitanjima kao »vjerojatno « obilježje SPE-a, no ne uvrštava ga u glavna obilježja prema kojima određuje areu niti detaljnije opisuje njegovu rasprostranjenost. Već spomenuta Dryerova (2013a) studija pokazuje da su jezici u kojima se polarna pitanja kodiraju jedino posebnim redom riječi vrlo rijetki na svijetu, a od trinaest takvih jezika u uzorku, devet ih je u Europi. Dryerovi podaci stoga govore u prilog tezi da rasprostranjenost pomicanja glagola na početak rečenice kao upitne konstrukcije u Europi treba pripisati arealnosti. Međutim, kao što je već naznačeno u Uvodu, on jezike koji uz poseban red riječi imaju i upitnu česticu svodi pod tip s upitnom česticom te zbog toga ne prikazuje sasvim vjerno koliko je pomicanje glagola u polarnim pitanjima prošireno po Europi.

\section{Ciljevi}

Ciljevi se ovoga rada mogu podijeliti u dvije skupine: one koji se odnose specifično na hrvatski i one koji se odnose na čitav SPE. Specifični su ciljevi za hrvatski opisati konstrukcije polarnih pitanja u suvremenom jeziku i prikazati njihov dija- 
kronijski razvoj. Pritom smo pokušali ispitati odražava li taj razvoj arealne utjecaje te kako se hrvatski uklapa u svoj arealni kontekst.

$\mathrm{Na}$ razini SPE-a, cilj je istražiti koji su tipovi polarnih upitnih konstrukcija zastupljeni na kontinentu te postoji li dominantan tip. Time smo nastojali provjeriti hipotezu da je jezičnom areom načelno proširen jedan tip upitne konstrukcije na primjeru SPE-a. Također je cilj ispitati koji su bili smjerovi međujezičnih utjecaja unutar SPE-a i kakve su promjene među različitim jezičnim stadijima s obzirom na način kodiranja polarnih pitanja posvjedočene. Zbog toga su u istraživanje uključeni i suvremeni i stari jezici. Za arealno kontekstualiziranje hrvatskoga bilo je važno obuhvatiti jezike koji su mu geografski bliski te su bili u dodiru s njim, a za dijakronijski opis što više slavenskih jezika, kako bi se omogućio bolji uvid u ishodišni sustav za hrvatski.

Rad bi trebao pridonijeti boljemu razumijevanju arealnih utjecaja kojima je hrvatski bio izložen i njegova položaja unutar europske jezične aree, a istovremeno bi trebao biti i doprinos raspravi o obilježjima SPE-a.

\section{Metodologija}

Rad se s jedne strane temelji na iščitavanju gramatika velikoga broja europskih jezika i određivanju tipa kodiranja polarnih pitanja za svaki. Pritom smo osobito usmjerili pozornost na tri parametra: pomiče li se glagol na početak rečenice u polarnim pitanjima, postoji li upitna čestica i, ako postoji, koji je njezin položaj u rečenici. Budući da u dostupnim gramatikama nekih jezika ove informacije nisu jasno iznesene - naročito ona o pomicanju glagola - poslužili smo se i drugim relevantnim opisima tih jezika. Na upitnu intonaciju nismo usmjerili pozornost jer se u gramatikama često ne spominje, a za stare jezike podatak i ne može biti dostupan.

U istraživanje je, osim hrvatskoga, uključeno deset jezika iz prošlosti 44 suvremena europska jezika. Od jezikā iz prošlosti, tri su starovjekovna: starogrčki, latinski i gotski, a šest je srednjovjekovnih: staroirski, staronordijski, staroslavenski te starofrancuski, starotalijanski i starošpanjolski. Stari su jezici važni za našu studiju kako bi se pokazalo kakve su upitne konstrukcije u Europi posvjedočene najranije i u kojoj su grani indoeuropskih jezika određeni tipovi konstrukcija najprije zabilježeni. U tom su nam smislu naročito važni starovjekovni jezici jer su posvjedočeni prije najvjerojatnijega nastanka SPE-a. K tomu za sve dosad navedene jezike osim gotskoga postoje jezici u današnjoj Europi koji se mogu smatrati njihovim nasljednicima, što bi nam trebalo omogućiti uvid u promjene posvjedočene u sustavima polarnih pitanja. Deseti je jezik iz prošlosti venecijanski iz 18. stoljeća, koji je uvršten jer se može očekivati da je bio u dodiru s hrvatskim. Od suvremenih jezika, njih 38 pripada indoeuropskoj jezičnoj porodici, a to su novogrčki, albanski, dvanaest baltoslavenskih jezika među kojima su dva baltijska i deset slavenskih, jedanaest germanskih, devet romanskih te četiri keltska jezika. Novogrčki, romanski, sjevernogermanski jezici te bugarski i makedonski imaju pretke među obuhvaćenim 
starim jezicima te stoga pružaju uvid i u dijakroniju upitnih konstrukcija. Novogrčki, albanski, makedonski, bugarski i rumunjski članovi su balkanskoga jezičnog saveza te bi trebali pokazati postoji li tip upitne konstrukcije tipičan za taj savez ije li on utjecao na hrvatski. Osim toga, talijanski i njemački bili su u dugotrajnom dodiru s hrvatskim. Preostale jezike čine četiri uralska, jedan turkijski i genetski izolirani baskijski, koji su važni za naše istraživanje kako bi bili uključeni i jezici izvan indoeuropske porodice. Među ovima su mađarski i turski, koji su bili u dugotrajnom kontaktu s hrvatskim.

\begin{tabular}{|c|c|c|c|c|}
\hline & indoeuropski & uralski & turkijski & izolirani \\
\hline \multirow[t]{2}{*}{ starovjekovni } & 3 & \multirow[t]{2}{*}{-} & \multirow[t]{2}{*}{-} & \multirow[t]{2}{*}{-} \\
\hline & \begin{tabular}{|l|} 
grčki: 1 \\
germanski: 1 \\
italski: 1 \\
\end{tabular} & & & \\
\hline \multirow{2}{*}{$\begin{array}{l}\text { srednjovjekovni i } \\
\text { novovjekovni }\end{array}$} & 7 & \multirow[t]{2}{*}{-} & \multirow[t]{2}{*}{-} & \multirow[t]{2}{*}{-} \\
\hline & $\begin{array}{l}\text { baltoslavenski: } 1 \\
\text { germanski: } 1 \\
\text { romanski: } 4 \\
\text { keltski: } 1\end{array}$ & & & \\
\hline \multirow[t]{2}{*}{ suvremeni } & 38 & 4 & 1 & 1 \\
\hline & $\begin{array}{l}\text { grčki: } 1 \\
\text { albanski: } 1 \\
\text { baltoslavenski: } 12 \\
\text { germanski: } 11 \\
\text { romanski: } 9 \\
\text { keltski: } 4\end{array}$ & $\begin{array}{l}\text { ugrofinski, ugrijski: } 1 \\
\text { ugrofinski, } \\
\text { finsko-samski: } 3\end{array}$ & južni: 1 & baskijski \\
\hline
\end{tabular}

Tablica 1. Pregled jezičnoga uzorka prema razdoblju i genetskoj klasifikaciji

S druge strane, da bi se hrvatski opisao i izvan suvremenoga standardnog jezika, podaci iz suvremenih normativnih gramatika nadopunjeni su građom iz dijakronijskoga rječnika te pretraživanjem mrežnih korpusa i upitnikom.

U svrhu prikazivanja razvoja pojedinih upitnih konstrukcija, poslužili smo se dijakronijskim Akademijinim rječnikom i pretražili smo njihove potvrde u povijesnim korpusima, Hrvatskoj jezičnoj riznici (Riznici) i potkorpusu Marulićevih djela unutar Hrvatskog nacionalnoga korpusa. Riznica obuhvaća različite vrste tekstova poput književnih, publicističkih, novinskih i udžbenika od 16. stoljeća do suvreme- 
noga doba, a za naše su potrebe posebno bili važni oni iz razdoblja prije suvremenoga standarda.

S ciljem opisa suvremenoga nestandardnog jezika, istražili smo Hrvatski mrežni korpus ( $\mathrm{hrWaC})$, koji je sastavljen od tekstova s internetske domene .hr. Budući da obuhvaća građu s forumā, blogova i slično, trebao bi razmjerno dobro predstavljati suvremeni razgovorni jezik. Međutim, ipak treba imati na pameti da je razgovornost ovih tekstova ograničena pisanim modalitetom.

Osim toga, preko internetskoga obrasca proveli smo anketu s 53 ispitanika, u kojoj je trebalo zadane izjavne rečenice preoblikovati u polarna pitanja, a potom ocijeniti prihvatljivost odabranih upitnih rečenica iz hrWaC-a na skali od 1 do 5 , pri čemu 1 označava sasvim neprihvatljivo, a 5 sasvim prihvatljivo i prirodno. Od ispitanikā su također prikupljeni podaci o dobi i obrazovanju, kao i o mjestima u kojima su odrasli i u kojima žive, kako bi se moglo ustvrditi može li se sklonost pojedinim konstrukcijama povezati s određenim geografskim područjima. Pritom nam je osobito važna informacija o mjestu u kojem je ispitanik odrastao, jer pretpostavljamo da je za većinu govornikā ono najviše utjecalo na njihov idiolekt. Svjesni smo činjenice da je poistovjećivanje prostora i dijalekata problematično, naročito za veće urbane sredine, no smatramo da ovakav pristup svejedno može pružiti uvid u neke tendencije.

Izjavne rečenice koje su ispitanici trebali preoblikovati u polarna pitanja odabrane su tako da pokrivaju sve finitne glagolske oblike koji se rabe u razgovornom jeziku, a mogu se pojaviti u upitnim rečenicama - prezent, perfekt, futur prvi i kondicional prvi:

\begin{tabular}{|l|l|}
\hline prezent & Tojeu redu. \\
& Možešmi pomoći. \\
& Ivica čita knjigu. \\
& Svida ti se ova pjesma. \\
& Gladni ste. \\
\hline perfekt & Marica je dobila peticu iz matematike. \\
& Već smo gledali taj film. \\
& Oni su to napravili. \\
\hline futur prvi & Sutra ćemo ići na kupanje. \\
& Posudit ćeš mi knjigu. \\
\hline kondicional prvi & Htjela bi sladoled. \\
& Bilo bi vam drago da se to ostvari. \\
\hline
\end{tabular}

Tablica 2. Pregled izjavnih rečenica danih na preformuliranje u polarne upitne prema glagolskom obliku njihova predikata

Rečenicama iz hrWaC-a koje smo dali na procjenu prihvatljivosti nastojali smo dobro obuhvatiti nestandardne upitne konstrukcije i varijacije u morfosintaktičkim obilježjima predikata za koje smo smatrali da bi mogle utjecati na prihvatljivost 
pojedinih konstrukcija. Pritom nam je naročito bilo važno uključiti konstrukcije za koje smo pretpostavili da nisu svim govornicima prihvatljive (npr. Halo, jel sam dobila stan Jurakić?, Jel si slobodan sutra?), kako bi se moglo pokazati koliko su one raširene.

Raspon dobi ispitanikā kreće se između 20 i 47 godina, ali njih 86.79 \% spada u skupinu između 23 godine i 25 godina, stoga anketa odražava govor mlađih govornika. Što se tiče obrazovne strukture, $49.06 \%$ ispitanika ima visoku naobrazbu (dodiplomski ili diplomski studij ili više), njih 37.74 \% ima višu naobrazbu (višu školu ili preddiplomski studij), a $11.32 \%$ srednju. Prema tome, naši su ispitanici iznadprosječno obrazovani i ne predstavljaju reprezentativan uzorak po tom obilježju. Ispitanici ne tvore reprezentativan uzorak ni po regiji podrijetla ili materinjem dijalektu. S 32.08 \% najveća su skupina ispitanici odrasli u Dubrovniku, a zatim ispitanici odrasli u Zagrebu ili okolici s $28.3 \%$. Po nekoliko je ispitanika iz Zagorja, Istre, Slavonije i Dalmacije (osim Dubrovnika).

\begin{tabular}{|l|l|l|}
\hline $20-24$ godine & $25-30$ godina & $>30$ godina \\
\hline $47(88.68 \%)$ & $5(9.43 \%)$ & $1(1.89 \%)$ \\
\hline
\end{tabular}

Tablica 3. Raspodjela ispitanikā po dobnim skupinama

\begin{tabular}{|l|l|l|}
\hline SŠS & VŠS & VSS \\
\hline $6(11.32 \%)$ & $27(50.94 \%)$ & $20(37.74 \%)$ \\
\hline
\end{tabular}

Tablica 4. Raspodjela ispitanikā po razini obrazovanja

Valja istaknuti da naša anketa nije ni zamišljena kao sociolingvističko ili dijalektološko istraživanje. Njezin je cilj bio tek okvirno ispitati koliko su pojedine upitne konstrukcije zastupljene, jesu li ograničene morfosintaktičkim kontekstom i postoje li razlike među različitim krajevima Hrvatske.

\section{Hrvatski jezik}

Svaka je upitna rečenica u hrvatskome obilježena posebnom uzlaznom intonacijom, a daljnji su načini za izricanje polarnih pitanja čestice li, zar, da li i je li te pomicanje glagola na prvo mjesto. Kao što je već najavljeno, intonacija se ovdje neće posebno obrađivati.

\section{1. Čestica li i pomicanje glagola}

Zajedno s intonacijom, glavni je način izricanja polarnoga pitanja u standardnom jeziku pomicanje finitnoga glagola na početak rečenice, nakon kojega slijedi enklitička upitna čestica li (usp. Barić et al. 1997: 447, Katičić 2002: 378, Silić i Pranjković 2007: 253), primjerice: 
(3) Ide li Maricau školu?

Budući da iz toga proizlazi kako enklitika li u polarnim pitanjima uvijek stoji neposredno iza glagola, mogli bismo se zapitati može li se li protumačiti kao glagolski sufiks, a ova upitna konstrukcija kao upitna glagolska fleksija prema Dryerovoj (2013a) tipologiji. Smatramo da ipak nije tako, i to iz dvaju razloga. Prvi je što se čestica li osim u polarnim pitanjima može rabiti i u sadržajnim pitanjima i u uskličnim rečenicama, u kojima ne slijedi nužno iza glagola, a služi kao pojačivač (v. Silići Pranjković 2007: 253, Pranjković 2012: 38), na primjer:

(4) Gdjelije Ivica?

(5) Lijepog li dana!

Drugi je razlog što je moguća elipsa klitike li kod glagolā u koordinaciji:

(6) a) Pleše li ipjeva li Ivica?

b) Pleše li i pjeva Ivica?

Pretraga hrWaC-a pokazuje da takve strukture nisu česte, ali ipak su potvrđene, primjerice:

\section{(7) Slušate li ičitate privatno Cohena?}

S druge strane, elipsa flektivnih afikasa nikako nije moguća u hrvatskome:

(8) a) Marica hodaipjeva

b) ** Marica hoda ipjev.

Akademijin rječnik (1904-1910: 30) navodi da je čestica li praslavenskoga postanja, u hrvatskome prvi put posvjedočena u 15. stoljeću, te da je enklitika koja stoji iza prve fonetske riječi u rečenici. Tvrdi se da u polarnim pitanjima prije nje »obično«stoji finitni glagolski oblik, no ipak se navode i izuzeci iz starijega jezika:

(9) Vratitilićešse? (zbornik iz Dubrovnika, 1520.)

Autori rječnika smatraju da se polarnim pitanjima s li u kojima finitni glagol nije na prvome mjestu osobito često izriče »čuđenje, iznenađivanje, sumnja ili nezadovoljnost«, a mi bismo na temelju njihovih primjera dodali da je riječ koja stoji prije li načelno fokusirana. Potvrde za ovakve konstrukcije s česticom li pronašli smo i u potkorpusu Marulićevih djela unutar HNK-a:

(10) Ovolijemojanetjakinja, kasenevolji va tolikihmukah? (Mirakuli, Senj, 1508.)

(11) Mnogi li se plode, mnoga li njihjakost? (Marko Marulić, 16. st.) 
U ovakvoj uporabi li čak ne mora nužno stajati neposredno iza prve fonetske riječi u rečenici, premda se takvi primjeri uglavnom mogu povezati s formom stiha:

(12) Majko, u ovojplačnoj sjeni i ti li me, jaoh, ostavi? (Ivan Gundulić, 17. st.)

Ovakve su konstrukcije posvjedočene u hrvatskoj književnosti barem do kraja 18. stoljeća:

(13) Nuti, Gospodine, koji ne kratiš ikomu pomoći, kojemu trjebuju; ti li bi nas ostavio, ti li bi zaboravio nas pri naj većoj tjeskoći? (Ivan Marija Matijašević, 1783.)

Na ovome mjestu smatramo potrebnim osvrnuti se na tzv. kvaziupitne rečenice s česticom li koje izražavaju čuđenje. Pranjković (2012: 38) tvrdi da u takvim rečenicama i u današnjem hrvatskom ispred li može stajati neglagolska sastavnica, na kojoj je tada »vrlo jak emfatički rečenični naglasak«, odnosno našom terminologijom - taje sastavnica fokusirana. Autor pritom daje sljedeći konstruirani primjer:

\section{(14) Tilisitazvjerka!?}

Iako je prema našoj govorničkoj intuiciji ovakva konstrukcija prihvatljiva vrlo rubno ili nije uopće, možemo ustvrditi da je ona barem nekim govornicima suvremenog hrvatskoga prihvatljiva te pretpostaviti da postoje razlike s obzirom na dob ili dijalekt.

Nije jasno treba li primjere (9) - (13) tumačiti kao prave upitne rečenice kojima se traži potvrda za sadržaj izražen fokusiranim konstituentom ili kao kvaziupitne rečenice poput (14), koje izražavaju čuđenje nad tim sadržajem. Koliko smo uspjeli iščitati iz konteksta, barem u primjeru (11) zaista je riječ o zahtijevanju informacije:

$$
\begin{aligned}
& \text { »Tko su«, reče, «ovoj ki po varsih hode } \\
& \text { bljudući prohode? Ki gradi? Ka hitrost? } \\
& \text { Mnogi li se plode, mnoga li njihjakost?« (Marko Marulić, 16. st.) }
\end{aligned}
$$

Stoga smo skloni zaključiti da su se u starom hrvatskome upitne rečenice s početnim fokusiranim konstituentom i česticom li mogle upotrebljavati za zahtijevanje potvrde za sadržaj izražen tim konstituentom. Pritom pretpostavljamo da je ova struktura s vremenom gubila tu funkciju, ali je zadržala funkciju izraza čuđenja. S druge strane, na temelju proučenih potvrda zaključujemo da se u neutralnim polarnim upitnim rečenicama bez fokusa već u 16. stoljeću, a vjerojatno i otprije, finitni glagol pomiče na početak rečenice.

Polarna pitanja konstruirana s glagolom na prvome mjestu i česticom li dobro su posvjedočena u hrWaC-u. U našoj su anketi takve rečenice koje su im ponuđene 
redovito ocijenjene najvišim ocjenama prihvatljivosti, koje daju prosječnu ocjenu 4.4. Ako se izuzmu rečenice koje sadrže glagolski oblik je, koje su svi ispitanici preoblikovali u pitanje ovom strategijom, 38 je ispitanika od njih 53 barem jednom ovako postavilo pitanje, na primjer:

\section{(16) Bilihtjelasladoled?}

\section{2. Čestica zar}

U standardnom hrvatskome još postoji i čestica zar, koja izražava čuđenje i očekivanje negativnog odgovora. Čestica zar može biti proklitička ili naglašena, a dolazi na prvo mjesto u rečenici i ne uzrokuje pomicanje glagola (usp. Barić et al. 1997: 448, Katičić 2002: 149, Silić i Pranjković 2007: 254). Akademijin rječnik (1975: 336) navodi da je čestica turcizam te da je posvjedočena od 18. stoljeća. Budući da nije riječ o strategiji za neutralno zahtijevanje informacije, kojima se u ovome radu usredotočujemo, ovom se česticom nećemo detaljnije baviti.

\section{3. Čestica da li}

Osim toga postoji složena čestica da li, koja nije prihvaćena u suvremenom standardnom hrvatskom. ${ }^{4}$ Čestica da li naglašena je i stoji na početku polarnoga pitanja, a u njemu se ne događa nikakvo pomicanje glagola (usp. Barić et al. 1997: 447, Katičić 2002: 378, Silić i Pranjković 2007: 254).

$\mathrm{Za}$ ovu česticu odlučili smo uzeti u razmatranje i zavisnoupitne čestice jer $d a$ inače ima funkciju univerzalnoga zavisnog veznika te stoga smatramo opravdanim pretpostaviti da je upitna čestica da li možda potekla iz zavisnih rečenica. Elementi koji stoje na početku zavisnoupitnih rečenica, a ne mogu se upotrijebiti u izravnim upitnim rečenicama, dobro su posvjedočeni u drugim jezicima, npr. engleski whether $\mathrm{i}$ if, a posvjedočen je i razvoj upitne čestice iz takva elementa. 5 U ovome se kontekstu valja osvrnuti na tvrdnje da su zavisnoupitne rečenice uvedene nultim veznikom, koje iznose Antonić (2011) za srpski, Bulić (2013) za bosanski i Gligorić (2018) za hrvatski. Prema ovome tumačenju, čestica u polarnim i upitna zamjenica ili prilog u sadržajnim upitnim rečenicama služe isključivo kao oznaka upitnosti, a ne kao vezno sredstvo. Antonić (2011: 271-272) to stajalište argumentira među ostalim činjenicom da su čestica da li te upitne zamjenice i prilozi u zavisnoupitnim rečenicama uvijek naglašeni, dok zavisni veznik da te iste zamjenice i prilozi upotrijebljeni kao veznici relativne rečenice nisu naglašeni. Međutim, budući da nije poznato otkad je subjunktor da isključivo klitički, ipak smatramo hipotetski zamislivim da je naglašeno da li stajalo u zavisnoupitnim rečenicama prije nego $\mathrm{u}$ izravnim upitnim rečenicama.

4 Usp. npr. Hudeček i Vukojević 2007., gdje se tvrdi da ona pripada razgovornomu funkcionalnom stilu standardnogajezika.

5 V. $§ 6.1 .1$ za primjere. 
U čitavoj hrvatskoj književnosti prije 19. stoljeća autori Akademijina rječnika (1884 - 1886: 241) jednom su prepoznali neutralno polarno pitanje s da li, i to u zavisnoupitnoj rečenici:

(17) Jere ne pomisle da li bog svaka vi. (Marko Marulić, 16. st.)

Pretragom Riznice nismo pronašli nijednu takvu upitnu rečenicu s da li u starijoj književnosti. Prve potvrde da li kao neutralne upitne čestice datiraju iz sredine 19. stoljeća, a isto vrijedi za primjere koje Akademijin rječnik navodi nakon spomenute Marulićeve rečenice. Otad je upitna čestica da li prilično česta, a javlja se podjednako i u izravnim pitanjima i u zavisnoupitnim rečenicama:

(18) Adalimu se može to izaměriti? (Antun Nemčić, 1845.)

(19) sadkći upita mater, da lijoj haljina dobro stoji [...] (Miroslav Kraljević, 1863.)

U hrWaC-u je da li u svojstvu neutralne upitne čestice također dosta čest, a javlja se i u apokopiranom obliku dal:

(20) Dali Iran financira međunarodni terorizam?

(21) Dal se boriš protiv samovolje moderatora (naslov teme)?

Omjer zastupljenosti oblika da li i dal u izravnim pitanjima i zavisnoupitnim rečenicama provjerili smo na nasumičnim uzorcima 150 uporaba iz hrWaC-a. Neapokopirano da li u polarnim pitanjima u uzorku je podjednako često i u zavisnim rečenicama i u izravnim pitanjima - zavisna je rečenica s frekvencijom od $53.47 \%$ tek neznatno češća. Apokopirano dal, s druge strane, pokazalo se zamjetno češćim u zavisnim rečenicama $-69.67 \%$ potvrda u uzorku u takvim je konstrukcijama:

\section{(22) Kad sam išla probat i vidjet dal bi i on skočio - iznenadio me svojim pokušajem}

U starijem je jeziku da li posvjedočen kao upitna čestica koja kodira pitanje s čuđenjem i očekivanjem negativnoga odgovora. Akademijin rječnik navodi brojne primjere za ovakvu uporabu iz 16. i17. stoljeća te poneke do kraja 18. stoljeća:

\section{(23) Dali može zaboravit žena djetićka? (Nikša Ranjina, 16. st.)}

Konačno, slijed da li u starijoj književnosti javlja se i u službi suprotnoga ili dopusnoga veznika. 6 Takvu uporabu potvrđuje Akademijin rječnik, a posvjedočena je i u djelima Brne Karnarutića u Riznici.

Na temelju iznesenoga ne možemo potvrditi početnu hipotezu da da li kao upitna čestica potječe iz zavisnoupitnih rečenica, gdje je nastalo dodavanjem upit-

6 V. Štrkalj Despot (2012.) za suprotni veznik da u starim hrvatskim tekstovima. 
ne čestice li na opći zavisni veznik da. Nadalje, s obzirom na nepostojanje kontinuiteta i na to da Marulićev primjer koji Akademijin rječnik navodi ne smatramo uvjerljivim, nije uopće sigurno potječe li da li s neutralnim upitnim značenjem od čestice da li sa značenjem čuđenja iz 16. stoljeća.

U našoj su anketi tek rijetki ispitanici u zadatku u kojem je trebalo izjavne rečenice preoblikovati u pitanje upotrijebili česticu da li ili dal - od njih 53 to ih je učinilo samo troje. Ponuđena izravna pitanja iz korpusa konstruirana na taj način ukupno su po prihvatljivosti ocijenjena prosječnom ocjenom 2.87 na ljestvici od 1 do 5 . Pritom je svaka vrijednost od 1 do 5 dobro zastupljena, a ne mogu se ustvrditi nikakvi obrasci ni s obzirom na podrijetlo ispitanika. Zavisnoupitne rečenice s česticom da li pokazale su se pak znatno prihvatljivijima našim ispitanicima. Prosječna im je ocjena prihvatljivosti 3.75, a 36 ispitanika dalo im je ocjenu 4 ili 5 , dok ih je ocjenom 1 ili 2 ocijenilo 9 ispitanika.

\section{4. Čestica je li}

Upitnu česticu je li normativne gramatike spominju kao nestandardnu i razgovornu (usp. Barić et al. 1997: 448, Katičić 2002: 148-149). Ta je čestica naglašena i stoji na početku polarnog pitanja, u kojem ne dolazi do pomicanja glagola, a često se javlja u apokopiranom oblikujel',jel.

Očito je nastala od 3. lica nesvršenog prezenta pomoćnoga glagola ili kopule biti i čestice li u uobičajenoj upitnoj konstrukciji, koji su vjerojatno zajedno reanalizirani kao upitna čestica te prošireni na rečenice u kojima nema oblika je. Također je zamislivo da je njezin izvor dopunsko pitanje (engleski tag question) ili poštapalica je li, ${ }^{7}$ koji se mogu protumačiti kao skraćena struktura je li tako. Međutim, budući da dopunska pitanja češće dolaze nakon iskaza (usp. Mihaljević 1995: 23), u tom slučaju ne bi bilo jasno zašto je je li kao upitna čestica posvjedočeno isključivo na početku rečenice.

U literaturi se ne spominje s kojim se glagolskim oblicima u rečenici upitna čestica je li može rabiti, a po našoj govorničkoj intuiciji, ona nije jednako česta ni prihvatljiva sa svim glagolskim oblicima. Barić et al. i Katičić daju samo primjere s prezentom:

(24) Jeli se umivaš?

Akademijin rječnik (1904-1910: 606) navodi da je je li kao upitna čestica posvjedočeno od 18. stoljeća, i to »u sjevernijem krajevima«. Ni u rječniku se ne spominje s kojim glagolskim oblicima ta čestica može doći, ali u svim su danim primjerima jednostavni glagolski oblici, i to u jednom aorist, a u ostalima prezent:

(25) Iz one ljubavi je li se kaješ za sve grihe svoje? (Antun Kanižlić, 18. st.)

7 V. Metslang et al. (2017: 496, 513) za primjere razvoja upitnih čestica od dopunskih pitanja u drugim jezicima. 
U primjerima se čestica je li pojavljuje i u rečenicama s glagolskim oblikom je:

(26) Jelije on klinčac, kot samja rožica? (narodna pjesma)

U tekstovima u Riznici je li se kao upitna čestica kronološki najranije javlja 1863. u slavonskoga pisca Miroslava Kraljevića, gdje uvodi zavisnoupitnu rečenicu. Čestica je u izravnim polarnim pitanjima sporadično posvjedočena u književnim djelima kroz drugu polovicu 19. i20. stoljeće:

(27) Jelije donije vjetar sjugovinom [...] ?(Janko Polić Kamov, 1907.)

Potvrđena je i u rečenicama s enklitičkim oblicima pomoćnih glagola i kopule, a takve su potvrde često u dijalozima na kajkavskom:

(28) Jelije to gospodi spodobno? (Ksaver Šandor Gjalski, 1899.)

(29) Je lije Vaša Milost pokušala postići, da se s protivnicima pomiri? (Isidor Kršnjavi, 1926.)

U hrWaC-u je čestica je li, naročito apokopirana jel, vrlo česta. Dobro je posvjedočena i s glavnim glagolima i s enklitičkim oblicima pomoćnih glagola i kopule, primjerice:

(30) Kumicejel si ti možda iz Koprivnice?

(31) Jel si ikad čul da sam ja javno ili privatno govoril protiv kluba i igrača?

Rezultati naše elicitacije upućuju na to da se rasprostranjenost upitne čestice je l(i) kroz sustav razlikuje po dijalektima.

Kod rečenica u kojima je predikat glavni glagol u prezentu, 21 ispitanik upotrijebio jejeli ilijel barem u jednoj rečenici. Takve rečenice iz korpusa po prihvatljivosti su od 1 do 5 ocijenjene ukupnom prosječnom ocjenom 3.87, a 31 ispitanik ih je u prosjeku ocijenio ocjenom 4 ili višom.

Kod rečenica s glagolskim oblikom je, bio on kopula ili pomoćni glagol, nijedan ispitanik nije upotrijebio strukturu jel(i) je. Kod ostalih oblika prezenta glagola biti, i u službi kopule i pomoćnoga glagola, samo je jedna ispitanica odrasla u Koprivnici formulirala pitanje s ovom česticom, i to s oblikom el. Ponuđena pitanja s enklitičkim prezentom glagola biti i upitnom česticom je l(i) sva su po prihvatliivosti ocijenjena ispod 3. Prosječne im ocjene variraju između 2.08 i 2.87 , bez zamjetne razlike s obzirom na to o kojem je obliku riječ i je li glagol u službi kopule ili pomoćnoga glagola. Pritom su im više ocjene uglavnom davali ispitanici koji su odrasli u Zagrebu i okolici, Slavoniji i Podravini, a niske oni koji su odrasli u Dubrovniku, Dalmaciji i Istri.

Što se tiče rečenica s futurom, ponovno je jedino ispitanica odrasla u Koprivnici upotrijebila upitnu čestica je l(i), to jest varijantu $e l$, i to kod obje takve rečenice. Rečenice s futurom iz korpusa po prihvatljivosti su ocijenjene prosječnom ocjenom 2.68. Više ocjene uglavnom su došle od ispitanika odraslih u Zagrebu ili okolici te Istri, a ispitanici odrasli u Dubrovniku ili Dalmaciji većinom su dali najniže ocjene. 
Konačno, 14 je ispitanika u barem jednoj rečenici s kondicionalom upotrijebilo upitnu česticu jel, a svi su od njih odrasli u Zagrebu ili okolici, Zagorju, Slavoniji ili Podravini. Takve su ponuđene rečenice po prihvatljivosti prosječno ocijenjene srednjom ocjenom 3. Najvišim ocjenama ocijenili su ih uglavnom ispitanici odrasli u Zagrebu i okolici, Zagorju i Slavoniji, a ispitanici odrasli u Dubrovniku i Dalmaciji opet su većinom dali niske ocjene.

Na temelju iznesenoga može se zaključiti da jejel(i) još uvijek u procesu gramatikalizacije u opću upitnu česticu, a da se stupanj njezine uznapredovalosti razlikuje po dijalektima. Upitna čestica je l(i) u rečenicama s glavnim glagolima u prezentu proširena je u svim dijelovima Hrvatske. U rečenicama s kondicionalom, čini se, raširena je načelno u sjevernim krajevima, što obuhvaća Zagreb s okolicom, Zagorje, Podravinu i barem neke dijelove Slavonije. Čestica je najmanje zahvatila rečenice s enklitičkim oblicima pomoćnih glagola ili kopule, a čini se da je tu najdalje doprla u nekim kajkavskim govorima, koji ne uključuju urbani zagrebački. Iako se naša anketa nipošto ne može smatrati pravim dijalektološkim istraživanjem, rezultati ipak daju naslutiti da je je li kao upitna čestica prošireno na više sintaktičkih konteksta na relativno kompaktnom području na sjeveru. Čini se da se ta inovacija širila i preko dijalekatskih granica, budući da zahvaća i kajkavska i štokavska područja, te bi se stoga mogla protumačiti kao primjer točne predikcije teze da se pragmatički motivirana obilježja lako šire u prostoru na mikrorazini.

\subsection{Samo pomicanje glagola}

Autori Akademijina rječnika pod natuknicom li (1904-1910: 30) spominju da se ona često i izostavlja, »osobito po sjevernijem krajevima«. Dvadeset i sedmero naših ispitanika iz svih dijelova Hrvatske postavilo je pitanje stavljanjem glagola na prvo mjesto u rečenici bez čestice li barem jednom. Kod 22 ispitanika to je ograničeno na naglašene prezentske oblike pomoćnih glagola biti i htjeti te glagola biti i u leksičkom značenju:

(32) Jesu oni to napravili?

Preostalih petero, koji su iz Istre te Zagreba i okolice, upotrijebilo je i nenaglašene oblike glagolā biti i htjeti je i oblike pomoćnoga glagola biti u kondicionalu:

(33) Su oni to storili?

U zadatak s provjerom prihvatljivosti ovu konstrukciju nismo uključili.

\subsection{Pomicanje klitika}

U rečenicama koje sadrže klitički oblik ličnih zamjenica razvidno je da šestero od gore spomenutih 27 ispitanika zapravo nije nužno na početak rečenice pomaklo glagol, nego klitiku: 
(34) Mi moreš pomoć?

(35) Tise pježa ova pjesma?

Ispitanici koji su primijenili ovakvu konstrukciju najvećim se dijelom poklapaju s onima koji su klitičke oblike glagola biti i htjeti smjestili na početak upitne rečenice. Iznimka je samo jedna ispitanica iz Pule, koja je na tom položaju upotrijebila klitičke oblike zamjenica, ali ne i klitičke oblike glagolā.

Ova konstrukcija nije uključena u zadatak provjere prihvatljivosti.

\subsection{Upitna zamjenica}

Konačno, neki ispitanici iz čakavskih i kajkavskih krajeva, njih osmero, postavili su polarna pitanja upitnom zamjenicom u službi upitne čestice:

\section{(36) Kajsmo već gledali taj film?}

Uporabu zamjenice što u funkciji upitne čestice koja izražava očekivanje negativnoga odgovara, sa značenjem vrlo sličnim značenju čestice zar, za štokavski potvrđuju Akademijin rječnik (1959-1962: 808-909) i Pranjković (2013: 242-243). Međutim, činjenica da je znatan broj čakavskih i kajkavskih ispitanika upotrijebio zamjenicu u svojstvu upitne čestice iako u anketi ničim nije implicirano da se pitanje postavi kao da je odgovor već očekivan, dok nijedan štokavac to nije učinio, upućuje na zaključak da se u njihovim govorima upitna zamjenica može rabiti i kao neutralna upitna čestica. Ovu bi pojavu svakako trebalo dodatno istražiti za pouzdanije zaključke.

Upitnu zamjenicu u funkciji čestice nismo uključili u zadatak s procjenom prihvatljivostijer je nismo predvidjeli kao način kodiranja neutralnoga polarnog pitanja.

\subsection{Pregled}

UTablici 5. danje sažetak rezultatā ankete o načinima kodiranja polarnih pitanja:

\begin{tabular}{|l|l|l|l|l|l|l|}
\hline & \multicolumn{1}{|c|}{$l i$} & dali & $\begin{array}{c}\text { jeli+ } \\
\text { prezent } \\
\text { gl.glagola }\end{array}$ & $\begin{array}{c}\text { jeli+pom. } \\
\text { gl. ilikopula }\end{array}$ & $\begin{array}{c}\text { samo } \\
\text { pomicanje } \\
\text { pom.gl. ili } \\
\text { kopule }\end{array}$ & $\begin{array}{c}\text { upitna } \\
\text { zamjenica }\end{array}$ \\
\hline $\begin{array}{l}\text { ispitanika } \\
\text { upotrijebilo }\end{array}$ & $\begin{array}{l}71.7 \\
\%\end{array}$ & $5.66 \%$ & $39,62 \%$ & $26,42 \%$ & $33,96 \%$ & $15,09 \%$ \\
\hline $\begin{array}{l}\text { prihvatlji- } \\
\text { vost }(1-5)\end{array}$ & 4,4 & 2,87 & 3,87 & 2,61 & - & - \\
\hline
\end{tabular}

Tablica 5. Konstrukcije polarnih pitanja u hrvatskom po udjelu ispitanika koji su ih upotrijebili i prosječnoj ocjeni prihvatljivosti 
Rezultati upućuju na to da je najstarija konstrukcija, čestica li s pomicanjem glagola na prvo mjesto, još uvijek najzastupljenija. Međutim, treba imati na umu da je nedostatak ovakve vrste upitnika što ispitanici svjesno razmišljaju o konstrukciji koju će upotrijebiti te su skloni odabrati prestižnije i standardne oblike umjesto onih koji su im možda češći u spontanom govoru. Osim toga, zanimljivo je da ispitanici u prosjeku daju malo nižu ocjenu prihvatljivosti konstrukciji s česticom je li i pomoćnim glagolom i kopulom nego konstrukciji s česticom da li, iako je prethodnu znatno više ispitanikā upotrijebilo. Ova se činjenica može povezati s tim što je da li ipak prihvatljivije od je li u višem registru, što vjerojatno utječe i na stav govornika o prihvatljivosti pojedinih konstrukcija. Također se pokazalo, prema našem tumačenju rezultatā, da je u nekim čakavskim i kajkavskim govorima upitna zamjenica vjerojatno gramatikalizirana u neutralnu upitnu česticu.

Konačno, u Tablici 6. prikazane su iznesene informacije o prvom posvjedočenju u hrvatskome i sintaktičkom ponašanju pojedinih neutralnih upitnih čestica:

\begin{tabular}{|l|l|l|l|}
\hline & posvjedočeno od & položaj u rečenici & pomicanje glagola \\
\hline$l i$ & 15. st. (vjerojatno prasl.) & drugo mjesto & da \\
\hline dali & ?16.st./19.st. & prvo mjesto & ne \\
\hline$j e l i$ & 18. st. & prvo mjesto & ne \\
\hline$? c ̌ a / k a j$ & $?$ & prvo mjesto & ne \\
\hline
\end{tabular}

Tablica 6. Upitne čestice u hrvatskom, vrijeme njihova prvoga posvjedočenja i sintaktičko ponašanje

\section{Drugi europski jezici}

U ovome će se poglavlju predstaviti te analizirati načini kodiranja polarnih pitanja u odabranim starim i suvremenim europskim jezicima. Kao polazište se uzima Dryerovo (2013a) istraživanje. Ono uključuje velik broj europskih jezika te pokazuje da je najčešća upitna strategija u Europi, kao i u ostatku svijeta, upitna čestica. Slijedi je na svijetu vrlo rijedak upitni red riječi, a rjeđe su konstrukcije sama upitna intonacija i specijalizirana glagolska fleksija. Kako je već rečeno u Uvodu, Dryerova je studija prilagođena velikomu uzorku jezikā iz cijeloga svijeta te ne otkriva sve detalje o pojedinim jezicima, primjerice formuliraju li se polarna pitanja istovremeno pomicanjem glagola i česticom. Osim toga, njegovim istraživanjem nisu obuhvaćeni podaci iz starih jezika, koji su nam potrebni kako bismo mogli donijeti zaključke o podrijetlu pojedinoga obilježja i smjeru međujezičnih utjecaja. 


\subsection{Podaci iz drugih europskih jezika i analiza}

Načini kodiranja polarnih pitanja ovdje će se sažeto izložiti te analizirati prema tipu strategije, krenuvši od starih jezika ako imaju relevantne potvrde. Puni skup podataka predstavljen je u Tablici 7, \$6.1.7.

\subsubsection{Upitna čestica}

Svi analizirani starovjekovni europski jezici imaju upitnu česticu, kao i staroirski i staroslavenski. Novogrčki i svi romanski jezici izgubili su neutralnu upitnu česticu koja je zabilježena u njihovim jezicima precima, što govori u prilog tezi o dijakronijskoj nestabilnosti toga pragmatičkog obilježja. Nepostojanje upitne čestice moglo bi se razmotriti kao arealno obilježje zapadne i srednje Europe, budući da je nema velika većina romanskih i germanskih jezika, kao ni češki. Romanski i germanski jezici rijetko su razvili novu upitnu česticu. Među iznimke spadaju sicilijanski, koji je u upitnu česticu gramatikalizirao upitno-odnosnu zamjenicu:

$\begin{array}{ll}\text { Chi sì } & \text { surdu? } \\ \text { Q biti.PRS.2SG } & \text { gluh.M.SG } \\ \text { "Jesiligluh?« } & \text { (P }\end{array}$

(Privitera 1998: 41)

Iznimke su također njemački, niskonjemački i jidiš, u kojima se veznik zavisnoupitne rečenice može rabiti i u glavnim polarnim upitnim rečenicama kao rjeđa alternativa. U potonjem je riječ o elementu ci, koji je posuđen od slavenskoga či (poljski czy, ukrajinski чu):

$\begin{array}{llll}C i & \text { farštejt } & \text { er } & \text { španiš? } \\ \mathbf{Q} & \text { razumjeti.PRS.3SG } & \text { 3SG.M.NOM } & \text { španjolski } \\ \text { »Razumijeli on španjolski?« } & \text { (Jacobs 2005: 229) } & \end{array}$

U većini jezikā u uzorku koji imaju upitnu česticu ona se pozicionira na prvo mjesto u rečenici, primjerice u litavskome:
Ar tu
ateisi
vakare?
Q 2SG.NOM
doći.FUT.2SG
večer.LOK.SG
»Hoćeš li ti doći navečer?«
(Ambrazas et al. 2006: 712)

Zadnje mjesto u rečenici posvjedočeno je jedino u turskome i estonskome, premda je globalno u jezicima s poretkom SOV zadnje mjesto najčešći položaj upitne čestice, a u jezicima s poretkom SVO ono je podjednako često kao prvo. Pritom u turskome čestica može biti i na nekom drugom položaju u rečenici ako je neki neposljednji konstituent fokusiran, a ni turski ni estonski nemaju nijedno od Haspelmathovih jedanaest obilježja SPE-a. Od analiziranih jezika čakilatinski, kojijejezik s poretkom SOV, ima česticu na drugome ili prvome mjestu. Gotski, staroslavenski, 
finski i samski enklitičku česticu smještaju na drugo mjesto u rečenici, a isto je s česticom li u bugarskome, makedonskome, hrvatskome i ruskome, što vjerojatno predstavlja arhaizam iz praslavenskoga u odnosu na druge slavenske jezike. Iznimku među analiziranim jezicima predstavlja i baskijski s česticama koje se smještaju neposredno prije ili poslije finitnoga glagola dok položaj glagola nije nužno fiksan:

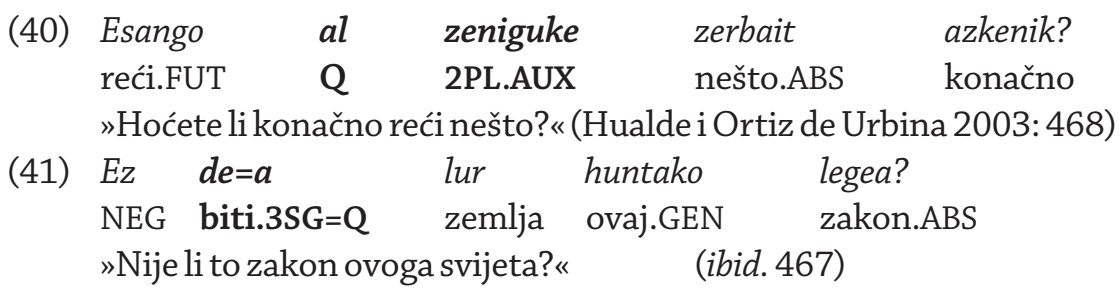

Iznimnost baskijskoga nije neočekivana s obzirom na to da se ni taj jezik ne smatra članom SPE-a.

S obzirom na predstavljene podatke, upitna čestica na prvome mjestu mogla bi se smatrati europskim arealnim obilježjem.

\subsubsection{Pomicanje glagola}

Pomicanje glagola na početak rečenice kao sredstvo kodiranja polarnoga pitanja nije posvjedočeno u starogrčkome, latinskome ni staroslavenskome, a redovito je u gotskome i staronordijskome, kao i svim suvremenim germanskim jezicima; primjerice u staronordijskom:

$\begin{array}{llllll}\text { (42) ok gekk pú } & \text { pó } & \text { ekki } & \text { haltr? } \\ \text { i ći.PST.2SG } & \text { 2SG.NOM pak NEG } & \text { šepav.M.NOM.SG } \\ \text { "Anisilišepao?« } & \text { (Faarlund 2004: 226) } & \end{array}$

Stoga se može zaključiti kako ovo obilježje valja pripisati već pragermanskomu te da se među europskim jezicima prvo pojavilo u germanskoj skupini. Čini se da se pomicanje glagola kao upitna konstrukcija razvilo i u srednjovjekovnim romanskim jezicima, što, u vezi s hipotezom da je to jedno od obilježjā SPE-a, kronološki odgovara vjerojatnomu vremenu nastanka toga jezičnog saveza i mogućemu germanskom utjecaju. Međutim, talijanski je do danas to obilježje izgubio, a ni u španjolskome pomicanje nije obvezno, nego samo uobičajeno ako je objekt kraći od subjekta ili ga nema (Butt i Benjamin 1989: 467-468). S druge strane, francuski i sjeveroistočni talijanski govori zadržali su pomicanje glagola kao oznaku upitnosti, a isto vrijedi za češki i slovenski. Spomenuti jezici bili su u dugotrajnijem i intenzivnijem dodiru s germanskim jezicima te je utemeljeno povezati njihovo stjecanje i zadržavanje pomicanja glagola u upitnim rečenicama s germanskim utjecajem. Valja napomenuti da keltski jezici uključeni u istraživanje imaju VSO kao kanonski 
poredak u izjavnim rečenicama, tako da početni glagol kao oznaka polarnog pitanja nije ni moguć.

Bugarski, makedonski i ruski nemaju inicijalni glagol u polarnim pitanjima kao beziznimno pravilo. Međutim, glagol ipak stoji na početku upitne rečenice s česticom li ako nijedan konstituent $u$ rečenici nije fokusiran, primjerice u ruskom:

\begin{tabular}{lcll} 
Прочитала & $л и$ & Анна & книгу? \\
pročitati.PST.F.SG & $\mathbf{Q}$ & Ana.NOM.SG & knjiga.ACC.SG \\
"Jeli Ana pročitala knjigu?» & \multicolumn{3}{c}{ (Halloway King 1994:92) }
\end{tabular}
Давноли он умер?
davno $\quad Q \quad$ 3M.SG umrijeti.PST.M.SG
"Je li on umro davno?»
(Wade 2011:509)

Budući da ovi jezici nisu bili u bliskom dodiru s germanskima, izvor toga obilježja ne treba tražiti u izvanjskim utjecajima. Moguće ga je tumačiti s polazišta da u tim jezicima prvo mjesto u rečenici i čestica li izražavaju fokus. Prema toj pretpostavci, može se zaključiti da se glagolom kao glavnim dijelom rečenice na prvome mjestu označava fokus na cijeloj upitnoj rečenici. Smatramo da pozivanje na fokus, koji shvaćamo kao upućivanje na postojanje alternativa (Krifka i Musan 2012: 7), svakako ima smisla kod polarnih pitanja jer ona po svome osnovnom značenju stavljaju u opreku dvije moguće istinosne vrijednosti nekoga iskaza. Finski i samski, koji nisu članovi SPE-a, imaju isti tip konstrukcije polarnog pitanja, a podaci iz turskoga - $\mathrm{u}$ kojem također upitna čestica na glagolu označava propitivanje cijelog iskaza, a na nekome drugom konstituentu fokus na tom elementu - također govore u prilog ovakvu tumačenju:

(45) Hasan gelecek=mi?

Hasan doći.FUT $=\mathbf{Q}$

"Hoće li Hasan doći?»

(Čaušević 2007: 18)

(46) Hasan=mi gelecek?

Hasan $=\mathbf{Q}$ doći.FUT (ibid.)

"Hoće li doći Hasan?«

Premda vrlo rijetko, i pomicanje glagola na kraj rečenice može biti povezano s upitnošću u nekim jezicima u uzorku. Riječje o njemačkome i niskonjemačkome, u kojima se izvorno zavisnoupitni veznik ob može rabiti i kao upitna čestica u glavnim rečenicama, pri čemu je finitni glagol na njezinu kraju kao u zavisnoj rečenici, npr.:

(47) Ob Peter heute kommt?

Q Petar danas doći.PRS.3SG

»Dolazi li Petar danas?« ～(Helbig i Buscha 1996: 612) 
Osim toga, Metslang et al. (2011: 152) spominju da se pomicanje glagola na kraj rečenice može upotrijebiti za postavljanje polarnog pitanja u estonskom, no to nije obvezno nitije najčešća konstrukcija.

\subsubsection{Upitna čestica i pomicanje glagola}

Kombinacija upitne čestice i pomicanja glagola prilično je rijetka. Posvjedočena je u okcitanskom:
(48) $E s=t i$
vòstra
biti.PRS.3SG=Q vaš.F.SG ruka REL 1SG.ACC dirati.PRS.3SG
»Dira li me vaša ruka?«
(Alibèrt 1976: 335)

Pod taj bi se tip konstrukcije moglo podvesti još njemačko i niskonjemačko ob s pomicanjem glagola na kraj rečenice te staronordijske ijidiške rečenice s hvárt odnosno ci, u kojima glagol mora slijediti neposredno nakon čestice, kao u sljedećem staronordijskom primjeru:

\begin{tabular}{|c|c|c|}
\hline Hvárt grcetr & pú & Skarpheðinn? \\
\hline $\begin{array}{l}\text { Q plakati.PRS.2SG } \\
\text { „Plačešlisada. Skarpheð }\end{array}$ & 2SG.NOM & sad Skarpheðinn.NOM.SG \\
\hline
\end{tabular}

\subsubsection{Klitički oblici zamjenica}

Francuski i stariji venecijanski s ishodišta inverzije glagola i subjekta gramatikalizirali su enklitičke oblike ličnih zamjenica na glagolu kao oznake polarnoga pitanja. Primjerice, u polarnim upitnim rečenicama u venecijanskom u 18. stoljeću, na glagol se dodaje enklitički oblik lične zamjenice (u danom primjeru la) koji se slaže sa subjektom u licu, rodu i broju:
(50) Vor=la che ghe parla da amiga? htjeti=3SG.F da 3SG.F.DAT govoriti.PRS.SBJV.1SG kao prijateljica „Želite li da Vam govorim kao prijateljici?« （Polo 2007: 226)

Polo (2007) uz opis osamnaestostoljetnog venecijanskoga kojije gore prenesen ne daje primjer u kojem je vidljivo da se klitička zamjenica lijepi na glagol i ako je subjekt izrečen posebnom imeničkom sintagmom, no za ilustraciju može poslužiti autoričin primjer iz današnjeg aldenskoga - uz glagol kao oznaka upitnosti stoji klitički oblik zamjenice (al) koji se slaže s izrečenim subjektom (Toni) u licu, rodu i broju:
(51) Vegni=al
doći.PRS.3SG=3SG.M Toni "Dolazi li Toni?»


U francuskome je također jedan od načinā kodiranja polarnoga pitanja naslanjanje oblika lične zamjenice koji se sa subjektom izrečenim imeničkom sintagmom slaže u licu, rodu i broju:

$\begin{array}{llll}\text { (52) } & \text { Marie } \quad \text { habitait=elle } & \text { à } & \text { Paris? } \\ \text { Marija } & \text { stanovati.IPF.3SG=3SG.F } & \text { u } & \text { Pariz } \\ \text { "Je li Marija živjela u Parizu?« } & \text { (Price 2013: 462) }\end{array}$

Elementi koji se dodaju na glagol radi izražavanja upitnosti, a sa subjektom se slažu u gramatičkim kategorijama, mogu se smatrati korakom prema razvitku upitnih afikasa. Budući da je ta upitna strategija u Europi vrlo rijetka, a s obzirom na pretpostavljenu arealnu difuznost, nije neočekivana činjenica da ju je venecijanski izgubio, a u razgovornom francuskome istiskuju je druge upitne konstrukcije.

\subsubsection{Sinteza}

U Tablici 7. dan je puni pregled najčešćih načina kodiranja neutralnoga polarnog pitanja po jeziku:

\begin{tabular}{|c|c|c|c|c|c|}
\hline jezik & $\begin{array}{l}\text { upitna } \\
\text { čestica }\end{array}$ & $\begin{array}{l}\text { položaj } \\
\text { upitne } \\
\text { čestice }\end{array}$ & $\begin{array}{l}\text { pomicanje } \\
\text { glagola na } \\
\text { prvo mjesto }\end{array}$ & $\begin{array}{c}\text { genetska } \\
\text { pripadnost }\end{array}$ & izvor \\
\hline starogrčki & $\tilde{\hat{\eta}}, \tilde{\alpha} \rho \alpha$ & \begin{tabular}{|l} 
prvo \\
mjesto
\end{tabular} & - & ie, grčki & $\begin{array}{l}\text { Smyth (1920: } \\
598)\end{array}$ \\
\hline latinski & $-n e$ & $\begin{array}{l}\text { drugo } \\
\text { mjesto }\end{array}$ & - & ie, ital. & $\begin{array}{l}\text { Pinkster (2015: } \\
\text { 323) }\end{array}$ \\
\hline gotski & $-u$ & $\begin{array}{l}\text { drugo } \\
\text { mjesto }\end{array}$ & + & ie, germ, is. & $\begin{array}{l}\text { Eythorsson } \\
(1995: 104)\end{array}$ \\
\hline staroirski & in & \begin{tabular}{|l|} 
prvo \\
mjesto
\end{tabular} & - & ie, kelt. & $\begin{array}{l}\text { Mac Eoin (1993: } \\
\text { 123) }\end{array}$ \\
\hline \multirow[t]{2}{*}{ staronordijski } & - & & + & \multirow{2}{*}{ ie, germ, sj. } & \multirow{2}{*}{$\begin{array}{l}\text { Faarlund (2004: } \\
\text { 226) }\end{array}$} \\
\hline & hvárt & $\begin{array}{l}\text { prvo } \\
\text { mjesto }\end{array}$ & $($ na drugo +$)$ & & \\
\hline staroslavenski & li & $\begin{array}{l}\text { drugo } \\
\text { mjesto }\end{array}$ & - & ie, bsl, slav. & $\begin{array}{l}\text { Večerka (1989: } \\
43-44)\end{array}$ \\
\hline starofrancuski & - & & + & ie, ital, rom. & $\begin{array}{l}\text { Einhorn (1974: } \\
130)\end{array}$ \\
\hline starotalijanski & - & & + & ie, ital, rom. & $\begin{array}{l}\text { Munaro (2010: } \\
1147)\end{array}$ \\
\hline starošpanjolski & - & & $+?$ & ie, ital, rom. & $\begin{array}{l}\text { Zauner (1921: } \\
112)\end{array}$ \\
\hline $\begin{array}{l}\text { venecijanski u } \\
18 . \text { st. }\end{array}$ & - & & $\begin{array}{l}\text { + (uz zamjenič } \\
\text { ki subjekt)/- }\end{array}$ & ie, ital, rom. & $\begin{array}{l}\text { Polo (2007: } \\
\text { 226-227) }\end{array}$ \\
\hline
\end{tabular}




\begin{tabular}{|c|c|c|c|c|c|}
\hline novogrčki & - & & $-/+$ & ie, grčki & \begin{tabular}{|l|}
$\begin{array}{l}\text { Arvaniti et al. } \\
(2006: 670)\end{array}$ \\
\end{tabular} \\
\hline albanski & $a$ & $\begin{array}{l}\text { prvo } \\
\text { mjiesto }\end{array}$ & - & ie, albanski & $\begin{array}{l}\text { (Newmark et al. } \\
\text { 1999: 319) }\end{array}$ \\
\hline \multirow[t]{2}{*}{ makedonski } & $\pi u$ & $\begin{array}{l}\text { drugo } \\
\text { miesto }\end{array}$ & $+/-$ & \multirow[t]{2}{*}{ ie, bsl, slav. } & \multirow{2}{*}{$\begin{array}{l}\text { (Friedman } \\
\text { 1993: 286- } \\
\text { 287), Rudin et } \\
\text { al. (1999:48) }\end{array}$} \\
\hline & дали & $\begin{array}{l}\text { prvo } \\
\text { mjesto }\end{array}$ & - & & \\
\hline \multirow[t]{2}{*}{ bugarski } & $л и$ & $\begin{array}{l}\text { drugo } \\
\text { mjesto }\end{array}$ & $+/-$ & \multirow[t]{2}{*}{ ie, bsl, slav. } & \multirow{2}{*}{$\begin{array}{l}\text { Antova et al. } \\
\text { (2002: } 208), \mathrm{Ru} \\
\text { din } \text { et al. (1999: } \\
48)\end{array}$} \\
\hline & дали & $\begin{array}{l}\text { prvo } \\
\text { mjesto }\end{array}$ & - & & \\
\hline \multirow[t]{2}{*}{ slovenski } & - & & + & \multirow[t]{2}{*}{ ie, bsl, slav. } & \multirow{2}{*}{$\begin{array}{l}\text { Toporišič (2000 } \\
516)\end{array}$} \\
\hline & $a l i, a$ & $\begin{array}{l}\text { prvo } \\
\text { mjesto }\end{array}$ & - & & \\
\hline ukrajinski & $4 и$ & $\begin{array}{l}\text { prvo } \\
\text { mjesto }\end{array}$ & - & ie, bsl, slav. & $\begin{array}{l}\text { Pugh i Press } \\
\text { (1999: 284- } \\
\text { 285) }\end{array}$ \\
\hline ruski & $\pi u$ & $\begin{array}{l}\text { drugo } \\
\text { mjesto }\end{array}$ & $+/-$ & ie, bsl, slav. & $\begin{array}{l}\text { Halloway King } \\
(1994: 92)\end{array}$ \\
\hline češki & - & & + & ie, bsl, slav. & $\begin{array}{l}\text { Naughton } \\
(2006: 213)\end{array}$ \\
\hline slovački & - & & - & ie, bsl, slav. & $\begin{array}{l}\text { Mistrík (1988: } \\
\text { 132) }\end{array}$ \\
\hline poljski & $c z y$ & $\begin{array}{l}\text { prvo } \\
\text { mjesto }\end{array}$ & - & ie, bsl, slav. & $\begin{array}{l}\text { Swan (2002: } \\
401)\end{array}$ \\
\hline \multirow{2}{*}{\begin{tabular}{|l} 
gornjolužičko- \\
srpski
\end{tabular}} & - & & + & \multirow[t]{2}{*}{ ie, bsl, slav. } & \multirow{2}{*}{$\begin{array}{l}\text { Stone (1993: } \\
656)\end{array}$} \\
\hline & $h a c ̌$ & $\begin{array}{l}\text { prvo } \\
\text { mjesto }\end{array}$ & - & & \\
\hline \multirow{2}{*}{$\begin{array}{l}\text { donjolužičko- } \\
\text { srpski }\end{array}$} & - & & + & \multirow[t]{2}{*}{ ie, bsl, slav. } & \multirow{2}{*}{$\begin{array}{l}\text { Stone (1993: } \\
656)\end{array}$} \\
\hline & lěc & \begin{tabular}{|l} 
prvo \\
mjesto
\end{tabular} & - & & \\
\hline litavski & $a r$ & $\begin{array}{l}\text { prvo } \\
\text { mjesto }\end{array}$ & - & ie, bsl, balt. & $\begin{array}{l}\text { Ambrazas et } \\
\text { al. (2006: 712- } \\
713)\end{array}$ \\
\hline latvijski & vai & \begin{tabular}{|l|} 
prvo \\
mjesto
\end{tabular} & - & ie, bsl, balt. & \begin{tabular}{|l} 
Mathiassen \\
$(1997: 226)$
\end{tabular} \\
\hline \multirow[t]{2}{*}{ njemački } & - & & + & \multirow[t]{2}{*}{ ie, germ, za. } & \multirow{2}{*}{$\begin{array}{l}\text { Helbig i Buscha } \\
\text { (1996: 611) }\end{array}$} \\
\hline & $a b$ & \begin{tabular}{|l|} 
prvo \\
mjesto
\end{tabular} & - & & \\
\hline \multirow[t]{2}{*}{ jidiš } & - & & + & \multirow[t]{2}{*}{ ie, germ, za. } & \multirow{2}{*}{$\begin{array}{l}\text { Jacobs (2005: } \\
\text { 228-229) }\end{array}$} \\
\hline & $c i$ & $\begin{array}{l}\text { prvo } \\
\text { mjesto }\end{array}$ & $($ na drugo +$)$ & & \\
\hline
\end{tabular}




\begin{tabular}{|c|c|c|c|c|c|}
\hline \multirow[t]{2}{*}{ niskonjemački } & - & & + & \multirow[t]{2}{*}{ ie, germ, za. } & \multirow{2}{*}{$\begin{array}{l}\text { Lindow et al. } \\
(1998: 251- \\
252)\end{array}$} \\
\hline & $a b$ & $\begin{array}{l}\text { prvo } \\
\text { mjesto } \\
\end{array}$ & - & & \\
\hline nizozemski & - & & + & ie, germ, za. & $\begin{array}{l}\text { van den Toorn } \\
(2008: 58-59)\end{array}$ \\
\hline frizijski & - & & + & ie, germ, za. & $\begin{array}{l}\text { Tiersma (1999: } \\
\text { 105-106) }\end{array}$ \\
\hline engleski & - & & $\begin{array}{l}+(\text { pomoćni, } \\
\text { modalni ili } \\
\text { »biti«) }\end{array}$ & ie, germ, za. & \\
\hline islandski & - & & + & ie, germ, sj. & $\begin{array}{l}\text { Thráinson } \\
(2007: 146- \\
147) \\
\end{array}$ \\
\hline ferski & - & & + & ie, germ, sj. & $\begin{array}{l}\text { Lockwood } \\
(1977: 154)\end{array}$ \\
\hline danski & - & & + & ie, germ, sj. & \begin{tabular}{|l} 
Lundskær- \\
Nielsen i Holmes \\
$(2010: 579)$ \\
\end{tabular} \\
\hline norveški & - & & + & ie, germ, sj. & $\begin{array}{l}\text { Faarlund et al. } \\
(1997: 925)\end{array}$ \\
\hline švedski & - & & + & ie, germ, sj. & $\begin{array}{l}\text { Teleman etal. } \\
(1999: 731)\end{array}$ \\
\hline rumunjski & - & & - & ie, ital, rom. & $\begin{array}{l}\text { Mallinson } \\
(1989: 409)\end{array}$ \\
\hline talijanski & - & & - & ie, ital, rom. & $\begin{array}{l}\text { Maiden i } \\
\text { Robustelli } \\
(2013: 147)\end{array}$ \\
\hline sardski & - & & - & ie, ital, rom. & $\begin{array}{l}\text { Jones (1993: } \\
24-25)\end{array}$ \\
\hline sicilijanski & chi & & - & ie, ital, rom. & $\begin{array}{l}\text { Privitera (1998: } \\
41)\end{array}$ \\
\hline \multirow[t]{2}{*}{ francuski } & - & & $\begin{array}{l}\text { + (uz zamje- } \\
\text { nički subjekt) } \\
\text { / - }\end{array}$ & \multirow[t]{2}{*}{ ie, ital, rom. } & \multirow[t]{2}{*}{$\begin{array}{l}\text { Price (2013: } \\
\text { 462-463) }\end{array}$} \\
\hline & $\begin{array}{l}\text { est-ce } \\
\text { que }\end{array}$ & $\begin{array}{l}\text { prvo } \\
\text { mjesto }\end{array}$ & - & & \\
\hline \multirow[t]{2}{*}{ okcitanski } & - & & + & \multirow[t]{2}{*}{ ie, ital, rom. } & \multirow{2}{*}{$\begin{array}{l}\text { Wheeler (1997: } \\
\text { 272) }\end{array}$} \\
\hline & $-t i$ & $\begin{array}{l}\text { drugo } \\
\text { mjesto/ } \\
\text { poslije } \\
\text { glagola }\end{array}$ & + & & \\
\hline
\end{tabular}




\begin{tabular}{|c|c|c|c|c|c|}
\hline katalonski & - & & - & ie, ital, rom. & $\begin{array}{l}\text { Wheeler et al. } \\
(1999: 486)\end{array}$ \\
\hline španjolski & - & & $+/-$ & ie, ital, rom. & $\begin{array}{l}\text { Butt i Benjamin } \\
(1989: 467- \\
468)\end{array}$ \\
\hline portugalski & - & & - & ie, ital, rom. & $\begin{array}{l}\text { Azevedo (2005: } \\
\text { 104-105) }\end{array}$ \\
\hline irski & $a n$ & $\begin{array}{l}\text { prvo } \\
\text { mjesto }\end{array}$ & - & ie, kelt. & $\begin{array}{l}\text { Mac Eoin (1993: } \\
\text { 139) }\end{array}$ \\
\hline škotski gaelski & an & \begin{tabular}{|l|} 
prvo \\
mjesto
\end{tabular} & & ie, kelt. & $\begin{array}{l}\text { Gillies (1993: } \\
\text { 212) }\end{array}$ \\
\hline \multirow[t]{2}{*}{ velški } & - & & - & \multirow[t]{2}{*}{ ie, kelt. } & \multirow{2}{*}{$\begin{array}{l}\text { Watkins (1993: } \\
\text { 337) }\end{array}$} \\
\hline & $a$ & $\begin{array}{l}\text { prvo } \\
\text { mjesto }\end{array}$ & - & & \\
\hline \multirow[t]{2}{*}{ bretonski } & $\begin{array}{l}h a(g), \\
\text { daoust } \\
(h a(g) \\
(-e \tilde{n}))\end{array}$ & $\begin{array}{l}\text { prvo } \\
\text { mjesto }\end{array}$ & - & \multirow[t]{2}{*}{ ie, kelt. } & \multirow[t]{2}{*}{$\begin{array}{l}\text { Stephens (1993 } \\
403)\end{array}$} \\
\hline & - & & - & & \\
\hline mađarski & - & & - & $\begin{array}{l}\text { uralski, } \\
\text { ugrofinski, } \\
\text { ugrijski }\end{array}$ & $\begin{array}{l}\text { Kenesei et al. } \\
(1998: 2)\end{array}$ \\
\hline finski & $-k o$ & $\begin{array}{l}\text { drugo } \\
\text { mjesto }\end{array}$ & $+/-$ & $\begin{array}{l}\text { uralski, } \\
\text { ugrofinski, } \\
\text { finsko- } \\
\text { samski }\end{array}$ & $\begin{array}{l}\text { Sulkala i } \\
\text { Karjalainen } \\
(2012: 8-9)\end{array}$ \\
\hline samski & $-g o$ & $\begin{array}{l}\text { drugo } \\
\text { mjesto }\end{array}$ & $+1-$ & $\begin{array}{l}\text { uralski, } \\
\text { ugrofinski, } \\
\text { finsko- } \\
\text { samski } \\
\end{array}$ & $\begin{array}{l}\text { Sammallahti } \\
(1998: 84)\end{array}$ \\
\hline \multirow[t]{2}{*}{ estonski } & kas, ega & $\begin{array}{l}\text { prvo } \\
\text { mjesto }\end{array}$ & - & \multirow{2}{*}{\begin{tabular}{|l|} 
uralski, \\
ugrofinski, \\
finsko- \\
samski \\
\end{tabular}} & \multirow[t]{2}{*}{$\begin{array}{l}\text { Metslang et al. } \\
(2011: 151)\end{array}$} \\
\hline & $v o \tilde{i} / v a ̈$ & $\begin{array}{l}\text { zadnje } \\
\text { mjesto }\end{array}$ & - & & \\
\hline turski & $-m i$ & \begin{tabular}{|l|} 
zadnje \\
mjesto
\end{tabular} & - & $\begin{array}{l}\text { turkijski, } \\
\text { južni }\end{array}$ & $\begin{array}{l}\text { (Čaušević 2007: } \\
\text { 18) }\end{array}$ \\
\hline \multirow[t]{3}{*}{ baskijski } & - & & $-1+$ & \multirow[t]{3}{*}{ izoliran } & \multirow{3}{*}{$\begin{array}{l}\text { Hualde \& } \\
\text { Ortiz de Urbina } \\
(2003: 467)\end{array}$} \\
\hline & $a$ & $\begin{array}{l}\text { poslije } \\
\text { glagola }\end{array}$ & $-/+$ & & \\
\hline & $a l$ & $\begin{array}{l}\text { prije gla- } \\
\text { gola }\end{array}$ & $-/+$ & & \\
\hline
\end{tabular}

Tablica 7. Pregled strategija za polarna pitanja po europskim jezicima 
Obrađeni podaci govore u prilog prihvaćanju početne hipoteze da u SPE-u postoje arealni obrasci u načinima kodiranja polarnih pitanja. Međutim, ipak ne možemo govoriti o jednome apsolutno dominantnom tipu konstrukcije, nego o barem dvama tipovima: upitnoj čestici smještenoj na početak rečenice i pomicanju glagola na početak upitne rečenice.

\subsection{Implikacije za hrvatski}

Pokazalo se da je kombinacija upitne čestice i pomicanja glagola kakvu nalazimo u hrvatskim polarnim upitnim rečenicama s li prilično rijetka među jezicima Europe. Paralelu među ovdje uključenim jezicima ima u okcitanskome te u nekim germanskim jezicima u kojima su izvorno zavisnoupitne rečenične strukture zadobile i samostalnu uporabu.

S obzirom na potvrde iz starije hrvatske književnosti (v. §5.1., primjeri (9) (13)) te podatke iz današnjega bugarskoga, makedonskoga i ruskoga, zaključujemo da se hrvatski u prošlosti najvjerojatnije poklapao s tim trima jezicima u tome što je početni položaj u upitnoj polarnoj rečenici zauzimao ili fokusirani konstituent ili finitni glagol ako fokusa nema. Razvoj prema današnjem strogom pravilu o finitnom glagolu na početku polarnoga pitanja (v. §5.1, primjer (3)) mogao bi se objasniti barem dvama razlozima. Kao prvo, smatramo opravdanim pretpostaviti da su polarna pitanja bez fokusa, dakle takva s glagolom na prvome mjestu, u uporabi bila češća od onih s fokusiranim konstituentom. Stoga se nastanak beziznimnoga pravila o inicijalnom glagolu s jedne strane može tumačiti kao poopćavanje najučestalije sintaktičke strukture na sve polarne upitne rečenice s česticom li. Kao drugo, također je utemeljeno razvoj obveznoga pomicanja glagola dovesti u vezu s njemačkim i venecijanskim utjecajima, budući da je riječ o jezicima s kojima je hrvatski bio u intenzivnom kontaktu. Međutim, tumačenje ove promjene u velikoj mjeri ovisi o općenitijim obrascima sintaktičkoga izražavanja fokusa u hrvatskome, koji u literaturi nisu dovoljno opisani. Svakako bismo dobili mnogo bolju sliku o predstavljenoj promjeni u polarnim upitnim rečenicama kad bismo mogli odgovoriti na pitanje uklapa li se ona u neku širu promjenu u načinima kodiranja fokusa, koja bi npr. mogla uključivati nastanak ograničenja u relativnom poretku fokusiranoga konstituenta iglagola.

U svjetlu zaključka da je inicijalni položaj upitne čestice europsko arealno obilježje, činjenica da se sve mlađe upitne čestice u hrvatskome, poput da li i jeli, smještaju na početak rečenice mogla bi se povezati s razvojem pod arealnim utjecajima. Čestica da li k tome vjerojatno odražava utjecaj balkanskejezične aree, sobzirom na to da u istom obliku postoji i u bugarskome i makedonskome, a nije naslijeđena iz praslavenskoga.

\section{Zaključne napomene}

U ovom su radu prvo opisane konstrukcije polarnih pitanja u hrvatskom jeziku i prikazan je njihov dijakronijski razvoj. Enklitička čestica li na drugome mjestu u 
rečenici najstariji je danas zastupljeni način kodiranja polarnih pitanja. U takvim pitanjima u suvremenom jeziku prije nje obvezno dolazi finitni glagolski oblik, a nekad je na prvome mjesto mogao biti i koji drugi konstituent ako je fokusiran. Mlađe su upitne čestice da li i je li, koje su smještene na početak rečenice, a je li je još uvijek u procesu gramatikalizacije. Daljnje su mlađe upitne konstrukcije glagol na prvome mjestu bez čestice i, u nekim govorima, upitna zamjenica gramatikalizirana kao upitna čestica.

Zatim su predstavljeni načini kodiranja polarnih pitanja u odabranim starim i suvremenim europskim jezicima, pod pretpostavkom da je to pragmatički motivirano jezično obilježje arealno difuzno, a s ciljem da se ustvrdi kako se hrvatski uklapa u svoj arealni kontekst te koji su bili smjerovi međujezičnih utjecaja. Na općenitijoj razini, također se nastojala provjeriti hipoteza da je u europskoj jezičnoj arei dominantan jedan tip polarne upitne konstrukcije. Pokazalo se da pomicanje glagola na početak rečenice u polarnom pitanju vjerojatno potječe iz germanskoga te se raširilo na neke susjedne negermanske jezike. S obzirom na podatke iz bugarskoga, makedonskoga i ruskoga, zaključuje se da se nastanak pravila o nužnom pomicanju glagola na prvo mjesto s česticom li u hrvatskome može objasniti sinergijom unutarjezičnih mehanizama te njemačkoga i možda venecijanskoga utjecaja. Nadalje, ispostavilo se da u Europi postoji tendencija prema konstrukciji polarnih pitanja s upitnim česticama na prvome mjestu u rečenici te se u taj kontekst može staviti i nastanak mlađih upitnih čestica da li i je li u hrvatskome. Obrađeni podaci govore u prilog početnoj hipotezi o postojanju arealnih obrazaca kod načinā kodiranja polarnih pitanja u Europi. Međutim, ipak nije riječ o jednome apsolutno dominantom tipu konstrukcije, nego o barem dvama tipovima koji se mogu smatrati arealnim obilježjima: čestici na prvome mjestu u rečenici i pomicanju finitnoga glagola na početak rečenice.

Ovim se radom pokušalo pokazati kako u europskoj jezičnoj arei postoje obrasci u kodiranju polarnih pitanja koji nisu posljedica zajedničkoga genetskog podrijetla, i da se oni odražavaju i na hrvatski. Svakako bi bilo zanimljivo dalje i detaljnije istražiti promjene u hrvatskoj sintaksi i njihove moguće uzroke i arealne implikacije. To se osobito odnosi na istraživanja o kodiranju fokusa, koja bi omogućila bolje kontekstualiziranje promjene u strukturi upitnih rečenica s česticom li.

\section{Literatura}

Akademijin rječnik (1884-1886) Rječnik hrvatskoga ili srpskoga jezika: Dio II. četa - đavḷi. Zagreb: Jugoslavenska akademija znanosti i umjetnosti.

Akademijin rječnik (1892-1897) Rječnik hrvatskoga ili srpskoga jezika: Dio V. kipak - leken. Zagreb: Jugoslavenska akademija znanosti i umjetnosti.

Akademijin rječnik (1898-1903) Rječnik hrvatskoga ili srpskoga jezika: Dio V. isprekrižati kipac. Zagreb: Jugoslavenska akademija znanosti i umjetnosti. 
Akademijin rječnik (1904-1910) Rječnik hrvatskoga ili srpskoga jezika: Dio VI. lekenički Moračice. Zagreb: Jugoslavenska akademija znanosti i umjetnosti.

Akademijin rječnik (1959-1962) Rječnik hrvatskoga ili srpskoga jezika: Dio 17. sunce - taj. Zagreb: Jugoslavenska akademija znanosti i umjetnosti.

Akademijin rječnik (1975) Rječnik hrvatskoga ili srpskoga jezika: Dio 22. zaklapača - zlotvor. Zagreb: Jugoslavenska akademija znanosti i umjetnosti.

Alibèrt, Loïs (1976) Grammatica occitana: Segon los parlars lengadocians. Montpellier: Centre d'estudis occitans.

Ambrazas, Vytautas, Emma Geniušienè, Aleksas Girdenis, Nijolè Sližienè, Dalija Tekorienè, Adelè Valeckienè i Elena Valiulytè (2006) Lithuanian Grammar. Vilnius: Baltos lankos.

Antonić, Ivana (2011) Клаузе с нултим везником. Tanasić, Sreto ur. Граматика и лексика у словенским језицима: зборник радова с међународног симпозијума. Novi Sad: Matica srpska, Beograd: Institut za srpski jezik SANU, 265-276.

Antova, Evgenia, Ekaterina Boytchinova i Poly Benatova (2002) A Short Grammar of Bulgarian for English Speaking Learners. Sofija: АВM Комерс.

Arvaniti, Amalia, Robert D. Ladd i Ineke Mennen (2006) Phonetic effects of focus and "tonal crowding" in intonation: Evidence from Greek polar questions. Speech Communication 48, 667-696.

Azevedo, Milton (2005) Portuguese: A Linguistic Introduction. Cambridge: Cambridge University Press.

Barić, Eugenija, Mijo Lončarić, Dragica Malić, Slavko Pavešić, Mirko Peti, Vesna Zečević i Marija Znika (1997) Hrvatska gramatika. Zagreb: Školska knjiga.

Bulić, Halid (2013) O »veznim sredstvima« zavisnoupitnih klauza. Bosanski jezik 10, 9-18.

Butt, John i Carmen Benjamin (1989) A New Reference Grammar of Modern Spanish. London: Edward Arnold.

Campbell, Lyle (2006) Areal Linguistics. Brown, Keith, ur. Encyclopedia of Language and Linguistics. Volume One. Boston: Elsevier, 456-460.

Čaušević, Ekrem (2007) Upitne rečenice u turskom jeziku. Prilozi za orijentalnu filologiju 57, 15-39.

Dryer, Matthew S. (2007) Word order. Shopen, Timothy, ur. Language Typology and Syntactic Description: Volume 1, Clause Structure. Cambridge: Cambridge University Press, 61-131.

Dryer, Matthew S. (2013a) Polar Questions. Dryer, Matthew S. i Martin Haspelmath, ur. The World Atlas of Language Structures Online. Leipzig: Max Planck Institute for Evolutionary Anthropology (dostupno na http://wals.info/chapter/116, pristup 20. travnja 2018.)

Dryer, Matthew S. (2013b) Position of Polar Question Particles. Dryer, Matthew S. i Martin Haspelmath, ur. The World Atlas of Language Structures Online. Leipzig, Max Planck Institute for Evolutionary Anthropology (dostupno na http://wals.info/chapter/81, pristup 20. travnja 2018.)

Einhorn, E. (1974) Old French: A Concise Handbook. Cambridge: Cambridge University Press.

Eythorsson, Thorhallur (1995) Verbal Syntax in the Early Germanic Languages. doktorska disertacija, Cornell University. 
Faarlund, Jan Terje, Svein Lie i Kjell Ivar Vannebo (1997) Norsk referansegrammatik. Oslo: Universitetsforlaget.

Faarlund, Jan Terje (2004) The Syntax of Old Norse. Oxford: Oxford University Press.

Friedman, Victor A. (1993) Macedonian. Comrie, Bernard i Greville G. Corbett, ur. The Slavonic Languages. London: Routledge, 249-305.

Gillies, William (1993) Scottish Gaelic. Ball, Martin J., ur. The Celtic Languages. London: Routledge, 145-227.

Givón, Talmy (2001) Syntax: A functional-typological introduction. Volume II. Amsterdam: John Benjamins Publishing Company.

Gligorić, Igor Marko (2018) Uzviki veznik: vrste riječi i (nad)rečenične službe. Osijek: Fakultet za odgojne i obrazovne znanosti u Osijeku.

Halloway King, Tracy (1994) Focus in Russian Yes-No Questions. Journal of Slavic Linguistics 2 (1), 92-120.

Haspelmath, Martin (1998) How young is Standard Average European? Language Sciences 20 (3), 271-287.

Haspelmath, Martin (2001) The European linguistic area: Standard Average European. Haspelmath, Martin, Ekkehard König, Wulf Oesterreicher i Wolfgang Raible, ur. Language typology and language universals. Handbücher zur Sprach- und Kommunikationswissenschaft. Berlin: de Gruyter, 1492-1510.

Helbig, Gerhard i Buscha, Joachim (1996) Deutsche Grammatik: Ein Handbuch für den Ausländerrunterricht. Leipzig: Langenscheidt Verlag Enzyklopädie.

Hualde, José Ignacio i Jon Ortiz de Urbina (2003) A Grammar of Basque. Berlin: Mouton de Gruyter.

Hudeček, Lana i Luka Vukojević (2007) Da li, je li i li - normativni status i raspodjela. Rasprave Instituta za hrvatski jezik i jezikoslovlje 33, 217-234.

Jacobs, Neil G. (2005). Yiddish: a Linguistic Introduction. New York: Cambridge University Press.

Jones, Michael Allan (1993) Sardinian Syntax. London: Routledge.

Katičić, Radoslav (2002) Sintaksa hrvatskoga književnogjezika. Zagreb: Hrvatska akademija znanosti i umjetnosti, Nakladni zavod Globus.

Kenesei, István, Robert Michael Vago i Anna Fenyvesi (1998) Hungarian. Descriptive Grammars. London: Routledge.

König, Ekkehard i Peter Siemund (2007) Speech act distinctions in grammar. Shopen, Timothy, ur. Language Typology and Syntactic Description: Volume 1, Clause Structure. Cambridge, Cambridge University Press, 276-324.

Krifka, Manfred i Renate Musan (2012) Information structure: Overview and linguistic issues. Krifka, Manfred i Renate Musan, ur. The Expression of Cognitive Categories (ECC). Berlin: Mouton de Gruyter, 1-43.

Lindow, Wolfgang, Dieter Möhn, Hermann Niebaum, Dieter Stellmacher, Hans Taubken i Jan Wirrer (1998) Niederdeutsche Grammatik. Leer: Verlag Schuster.

Mac Eoin, Gearóid (1993) Irish. Ball, Martin J., ur. The Celtic Languages. London, Routledge, 101-144. 
Maiden, Martin i Cecilia Robustelli (2013) A Reference Grammar of Modern Italian. London: Routledge.

Mallinson, Graham (1989) Rumanian. Harris, Martin i Nigel Vincent, ur. The Romance Languages. London: Routledge, 391-419.

Matasović, Ranko (2001) Uvod u poredbenu lingvistiku. Zagreb: Matica hrvatska.

Matasović, Ranko (2002) On Representing Syntactic Change: Towards a Theory of Diachronic Syntax. Suvremena lingvistika 53-54, 57-72.

Mathiassen, Terje (1997) A Short Grammar of Latvian. Bloomington: Slavica Publishers.

Metslang, Helle, Külli Habicht i Karl Pajusalu (2011) Developmental paths of interrogative particles: the case of Estonian. Folia Linguistica Historica 45, 149-187, https://doi.org/10.1515/flih.2011.006.

Metslang, Helle, Hülli Habicht i Karl Pajusalu (2017) Where do polar question markers come from? STUF - Language Typology and Universals 70 (3), 489-521. http://dx.doi.org/10.1515/stuf-2017-0022.

Mihaljević, Milan (1995) Upitne rečenice u hrvatskom jeziku. Suvremena lingvistika 39, 17-38.

Mihaljević, Milan (1997) Jestno-niječna pitanja u hrvatskom crkvenoslavenskom jeziku. Suvremena lingvistika 43-44 (1-2), 191-209.

Mistrík, Jozef (1988) A Grammar of Contemporary Slovak. Bratislava: Slovenské pedagogické nakladatel'stvo.

Munaro, Nicola (2010) La frase interrogativa. Salvi, Giampaolo i Lorenzo Renzi, ur. Grammatica dell'italiano antico, sv. 2, Bologna: Il Mulino, 1147-1185.

Naughton, James (2006) Czech. An Essential Grammar. London: Routledge.

Newmark, Leonard, Philip Hubbard i Peter Prifti (1999) Standard Albanian: A Reference Grammar for Students. Stanford: Stanford University Press.

Pinkster, Ham (2015) The Oxford Latin syntax. Volume 1, The simple clause. Oxford: Oxford University press, http://dx.doi.org/10.1093/acprof:oso/9780199283613.001.0001.

Polo, Chiara (2007) Synchronic and diachronic variation phenomena in inverted interrogative and related contexts in Northern Italian dialects. Nordlyd 34, 219-238.

Pranjković, Ivo (2012) Upitno, pojačajno, namjerno i uvjetno li. Pismo: Časopis za jezik i književnost 10 (1), 33-43.

Pranjković, Ivo (2013) Gramatička značenja. Zagreb: Matica hrvatska.

Price, Glanville (2013) A Comprehensive French Grammar. Malden: Blackwell Publishing.

Privitera, Joseph F. (1998). Basic Sicilian: A Brief Reference Grammar. Lewiston: Edwin Mellen Press.

Pugh, Stefan M. i Ian Press (1999) Ukrainian: A Comprehensive Grammar. London: Routledge.

Rudin, Catherine, Christina Kramer, Loren Billings, i Matthew Baerman (1999) Macedonian and Bulgarian li Questions: Beyond Syntax. Natural Language and Linguistic Theory 17 (3), 541-586

Sammallahti, Pekka (1998) Saamic. Abondolo, Daniel, ur. The Uralic Languages. London: Routledge, 43-95

Silić, Josip i Ivo Pranjković (2007) Gramatika hrvatskoga jezika. Zagreb: Školska knjiga. 
Smyth, Herbert Weir (1920) A Greek Grammar for Colleges. New York: American Book Company.

Stephens, Janig (1993) Breton. Ball, Martin J., ur. The Celtic Languages. London: Routledge, 349-409.

Stone, Gerald (1993) Sorbian. Combrie, Bernard i Greville Corbet, ur. The Slavonic Languages. London: Routledge, 593-685.

Sulkala, Helena i Merja Karjalainen (2012) Finnish. Descriptive Grammars. Abingdon: Routledge.

Swan, Oscar E. (2002) A Grammar of Contemporary Polish. Bloomington: Slavica.

Štrkalj Despot, Kristina (2012) Značenje i uporaba suprotnoga veznika da u starohrvatskim tekstovima. Filologija 59, 173-194.

Teleman, Ulf, Staffan Hellberg i Erik Andersson (1999) Svenska Akademiens grammatik 4. Satser och meningar. Stockholm: Svenska Akademien.

Thomason, Sara G. (2001) Language Contact. Edinburgh: Edinburgh University Press.

Thráinson, Höskuldur (2007) The Syntax of Icelandic. Cambridge: Cambridge University Press.

Tiersma, Peter Meijes (1999) Frisian Reference Grammar. Ljouwert: Fryske Akademy.

Toporišič, Jože (2000) Slovenska slovnica. Maribor: Založba Obzorja.

van den Toorn, Maarten C. (2008) Nederlandse grammatica. Groningen: Wolters-Noordhoff.

Večerka, Radoslav (1989) Altkirchenslavische (altbulgarische) Syntax I. Die lineare Satzorganisation. Freiburg: U. W. Weiher.

Velupillai, Viveka (2012) An Introduction to Linguistic Typology. Amsterdam: John Benjamins Publishing Company, http://dx.doi.org/10.1075/z.176.

Wade, Terence (2011) A Comprehensive Russian Grammar. Hoboken, Wiley-Blackwell.

Watkins, T. Arwyn (1993) Welsh. Ball, Martin J., ur. The Celtic Languages. London: Routledge, 289-348.

Wheeler, Max W. (1997) Occitan. Harris, Martin i Nigel Vincent, ur. The Romance Languages. London, Routledge, 246-278.

Wheeler, Max, Alan Yates i Nicolau Dols (1999) Catalan: A Comprehensive Grammar. London: Routledge. 


\section{Kratice}

Kratice korištene u glosama

$\begin{array}{llll}\text { ABS } & \text { apsolutiv } & \text { NOM } & \text { nominativ } \\ \text { ACC } & \text { akuzativ } & \text { PL } & \text { množina } \\ \text { AUX } & \text { pomoćniglagol } & \text { PRS } & \text { prezent } \\ \text { F } & \text { ženski rod } & \text { PST } & \text { prošlo vrijeme } \\ \text { FUT } & \text { futur } & \text { Q } & \text { upitna čestica } \\ \text { GEN } & \text { genitiv } & \text { REL } & \text { relativizator } \\ \text { LOC } & \text { lokativ } & \text { SBJV } & \text { konjunktiv } \\ \text { M } & \text { muški rod } & \text { SG } & \text { jednina }\end{array}$

NEG negacija

\section{Ostale kratice}

balt. baltijski

pom. pomoćni

bsl. baltoslavenski

rom. romanski

germ. germanski

S subjekt

gl. glagol

sj. sjeverni

hrWaC Hrvatski mrežni korpus

slav. slavenski

ie. indoeuropski

SPE standardni prosječni europski

ital. italski

V glagol

kelt. keltski

za. zapadni

o objekt

\section{Polar Interrogative Clauses in Croatian in a Diachronic and Areal-Typological Perspective}

Based on linguistic literature, corpus data and elicitation, this paper offers a description of polar question coding strategies in Croatian and presents their diachronic development. Under the assumption that pragmatically motivated features such as polar question markers are areally diffuse, Croatian is put in the context of European languages. An overview of interrogative constructions in selected ancient and modern languages is presented, showing that there are certain areal tendencies, which are reflected in Croatian as well, and that the development of particular interrogative constructions in Croatian may be interpreted in accordance with these tendencies.

Ključne riječi: polarno pitanje (lingvistika), upitna čestica, hrvatski jezik, europski jezični areal, arealna lingvistika

Keywords: polar question, question particle, Croatian language, European linguistic area, areal linguistics 